\title{
Cytotoxicity of Cichorium intybus L. metabolites (Review)
}

\author{
KHANDAKER MD SHARIF UDDIN IMAM*, YINGYING XIE*, YUSI LIU, FENGZHONG WANG and FENGJIAO XIN \\ Laboratory of Biomanufacturing and Food Engineering, Institute of Food Science and Technology, \\ Chinese Academy of Agricultural Sciences, Beijing 100193, P.R. China
}

Received December 3, 2018; Accepted July 19, 2019

DOI: 10.3892/or.2019.7336

\begin{abstract}
Cichorium intybus L. (Chicory) is a widely distributed, edible, perennial, herbaceous member of the Asteraceae family. Besides its use in modern Chinese herbal medicine, its ethnomedicinal use is evident in the text from ancient Greece, Egypt and China. It is also used as a food and coffee substitute, which is mainly responsible for its extensive domestication. In recent decades, cytotoxic studies of $C$. intybus extracts have shown its antitumor potential. These studies also identified metabolite constituents including guaianolides, 6-methoxyflavone, eudesmanolides, germacranolides, polyacetylene, sterol, anthocyanin, delphinidin, 3,4-dihydroxyphenethyl and other novel compounds. Many of these phytometabolites have shown positive cytotoxic activities in vitro, and antitumor action in vivo and in clinical trials, demonstrating the potential of C. intybus metabolites as antitumor drugs. Structural activity relationship studies have further confirmed these bioactivities. In this review, we focused on the phytochemicals of $C$. intybus with reported cytotoxicity and potential antitumor properties. We also discuss their specificity towards tumor cells, structural activity relationship, the involved signaling pathways and molecular mechanism, with the expectation of the future development of efficient and targeted antitumor therapeutic strategies.
\end{abstract}

\section{Contents}

1. Introduction

2. Literature search method

3. Antitumor activity of the phytochemicals

Correspondence to: Dr Fengzhong Wang or Dr Fengjiao Xin, Laboratory of Biomanufacturing and Food Engineering, Institute of Food Science and Technology, Chinese Academy of Agricultural Sciences, Nongda South Road, Beijing 100193, P.R. China

E-mail: wangfengzhong@sina.com

E-mail: 2002hongzhi30@163.com

${ }^{*}$ Contributed equally

Key words: chicory, phytometabolites, antitumor, structural activity relationship, signaling pathway
4. Molecular mechanisms

5. Toxicological studies

6. Clinical trials

7. Conclusion and perspectives

\section{Introduction}

Cichorium intybus L. is a perennial herbaceous plant and is one of the six members of the genus Cichorium under family Asteraceae. Although it is a native weed from Europe, $C$. intybus has been naturalized in different parts of the world including Africa, temperate and tropical Asia, Europe, Australia, North and South America (1,2). Its leaf is commonly used as a vegetable and powdered root as a coffee substitute; the whole plant is also used for animal forage (3). C. intybus L. has been used as a common medicinal herb worldwide in different civilizations. Ancient Egyptians (3) and Romans (mentioned by 'Horace' in 'Odes') used $C$. intybus as a medicinal plant. However, local nomenclature has vast differences, and so do the medicinal uses. Ethnomedicinal use of $C$. intybus covers diarrhea, liver diseases, prostate and reproductive organ disorder, pulmonary disease, cough, malaria and cancer (1). The recent use of $C$. intybus as an alternate for coffee has led to its commercial cultivation. $C$. intybus is also currently cultivated as a major source of inulin, a dietary fiber fructan (4).

As reviewed in the following sections, several studies have shown that phytochemicals may be a reliable source of compounds with therapeutic benefits. For example, many drugs derived from phytochemicals and their derivatives have shown promise and utility in tumor treatment. $C$. intybus contains diverse types of phytochemicals such as guaianolides, 6-methoxyflavone, eudesmanolides, germacranolides, polyacetylene, sterol, anthocyanin, delphinidin, 3,4-dihydroxyphenethyl and other novel compounds in different quantities. Fractionated and purified extracts of $C$. intybus have been the subject of many studies. Many researchers have reported the therapeutic properties of $C$. intybus compounds, on in vitro as well as in vivo models of tumors.

C. intybus phytochemicals have shown tissue- and tumor type-specific antitumor activity, which indicates against indiscriminate cytotoxicity and instead suggests the presence of a well-regulated mechanism. In this review, we summarize C. intybus derived phytochemicals with reported antitumor properties from traditional and pharmacological trials. We also review their cell specificities and antitumor mechanisms. 


\section{Literature search method}

We used PubMed (https://www.ncbi.nlm.nih.gov/pubmed/), Google Scholar (https://scholar.google.com), and Baidu Xueshu (http://xueshu.baidu.com) scientific article search engines as well as PubChem (https://pubchem.ncbi.nlm.nih.gov/), and U.S. National Library of Medicine (https://clinicaltrials. gov/) for the preliminary search. We searched for articles published between 1975 to 2018. Keywords such as chicory, Cichorium intybus, phytochemicals, phytometabolites, anticancer, antitumor, cytotoxic, and clinical trial were used individually or in combination to search for antitumor phytometabolites of $C$. intybus. Articles for each metabolite and its activity were searched individually within the same time frame. Chemical structures of metabolites were sourced primarily from research articles and using ChemDraw search and then confirmed from PubChem and Chem Spider databases. Chemical structures were drawn with ChemDraw according to journal guidelines. Illustrations were drawn in combination with ChemDraw and Adobe Illustrator.

\section{Antitumor activity of the phytochemicals}

The medicinal properties of $C$. intybus $\mathrm{L}$. led to many successful investigations to identify its phytochemical constituents. $C$. intybus is used in a variety of illnesses, and the phytochemicals derived from it are also diverse. Overall, our analysis revealed 87 reported phytochemicals, of which Carazzone et al (5) identified 63; Street et al (3) reported 84; and Malik et al (6) found 78. Several other studies also reported some of these phytochemicals. Most of these compounds show bioactivity, and some have multiple pharmacological properties. However, in the present review, we focus on the phytochemicals with reported antitumor properties, as listed in Table I.

Reactive oxygen species (ROS) are highly reactive radicals, ions or molecules with a single unpaired electron in their outermost shell. Recent studies have shown that ROS contribute to several diseases and disorders (6) including chronic inflammation and a wide variety of different cancers (7). ROS are categorized into two broad types: Free oxygen radicals such as superoxide, hydroxyl radical, nitric oxide, organic radicals, peroxyl radicals, alkoxyl radicals, thiyl radicals, disulfides, sulfonyl radicals, and thiyl peroxyl radicals; non-radical ROS such as hydrogen peroxide, singlet oxygen, ozone/trioxygen, organic hydroperoxides, hypochlorite, peroxynitrite, nitrosoperoxycarbonate anion, nitrocarbonate anion, dinitrogen dioxide, nitronium, and highly reactive lipid- or carbohydrate-derived carbonyl compounds (8). ROS are produced as an inevitable byproduct of cellular processes such as mitochondrial oxidative phosphorylation (8) and play vital roles in the stimulation of cell signaling pathways in response to intracellular and extracellular changes (7). In almost all cancers, the ROS concentration is elevated. However, to survive, cancer cells produce antioxidant proteins to detoxify $\operatorname{ROS}(8,9)$. In cancer cells, the ROS elevation can be caused by mitochondrial dysfunction, peroxisome activity, oncogene activity, increased metabolism, increased cellular receptor signaling, increased activity of oxidases, cyclooxygenases, lipoxygenases, and thymidine phosphorylase, as well as through crosstalk with infiltrating immune cells $(8,10)$. The difference between ROS and antioxidant levels creates oxidative stress. Free radicals produced by oxidative stress alter macromolecules such as DNA, proteins, and lipids, and thus play a significant role in inducing carcinogenesis $(7,10)$.

These altered macromolecules, unable to perform their function, can hinder cell growth and even cause death. However, a dysfunctional cell divisional mechanism causes uncontrolled cell division. For example, ROS can upregulate cyclin mRNA levels including cyclin B2, cyclin D3, cyclin E1, and cyclin E2; resulting in fast transition from the G1 to $S$ phase of the cell cycle (8). The uncontrolled cell growth results in a cell mass called a tumor. Afterward, these tumors, unable to support their growth, create new blood vessels around them, a process known as angiogenesis. These blood vessels facilitate growth of the tumors to a point after which cancerous cells start to detach from the malignant tumor and migrate through blood vessels to other tissues of the body known as metastasis (11). ROS can promote tumor cell metastasis by decreasing extracellular matrix anchorage or increasing vascular permeability (8). These transformed cell-containing organs are unable to function properly leading to organ failure and death (11). To be considered as an antitumor drug, the therapeutic agent should have the following qualities of counteracting tumorigenesis: i) counteract ROS; ii) counteract the oxidative stress caused by ROS; iii) prevent angiogenesis; iv) prevent the metastasis of cancerous cells; and v) selective cytotoxicity towards cancerous cells to induce apoptosis.

To be considered as a therapeutic agent, the compound must also show fewer side effects compared with existing antitumor drugs. The present review also describes the possibility of using $C$. intybus phytochemicals and their derivatives as potent tissue-specific antitumor agents.

In vitro studies have revealed the antitumor activities of whole and fractionated extracts of $C$. intybus and its parts with different solvents. A $100 \mu \mathrm{g} / \mathrm{ml}$ hydroalcoholic extract of $C$. intybus leaf was found to be significantly effective against a prostate cancer cell line ( $\mathrm{LNCaP}$; percent of inhibition: $3.67 \pm 0.12$ ) and a root extract was found to be significantly effective against breast cancer cells (MCF-7), amelanotic melanoma cells (C32) and renal adenocarcinoma cells (ACHN) (percent of inhibition: $12.65 \pm 0.26,30.78 \pm 0.75$, $14.93 \pm 0.29$, respectively) (12). A whole plant extract fed to a mouse carcinoma model (dimethyl hydrazine-induced) showed lower expression of natural interferon $\alpha$ (INF- $\alpha$ ), and B-cell lymphoma 2 (Bcl-2) and higher expression of interleukin (IL-12 and IL-4), confirming the antitumor property (13). A methanol extract of root from $C$. endivia, a related plant, was found to inhibit the growth of breast cancer cells (MCF-7; $\mathrm{IC}_{50}: 401 \mu \mathrm{g} / \mathrm{ml}$ ) in vitro (14), and a whole plant water extract inhibited tumor growth in a colorectal cancer mouse model in situ (200 mg/kg body weight) (15). The antitumor activity of a whole ethanolic extract of $C$. intybus root was demonstrated in an Ehrlich ascites carcinoma (EAC) mouse model, resulting in a 70\% increase in lifespan with $500 \mathrm{mg} / \mathrm{kg} / \mathrm{day}$ treatment (16). A comparative study between different plants showed that $C$. intybus seed water extract moderately reduced the development and colony formation in PC-3 prostate cancer cells (2-30\%), T47D breast carcinoma cells (2-21\%), and RKO 
Table I. Cichorium intybus L.-derived phytochemicals that exert antitumor properties.

Phytochemicals

\section{1,13-Dihydrolactucopicrin}

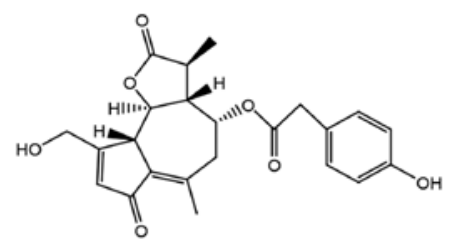

Putrescine

Spermidine

Caffeic acid

Chlorogenic acid

5-Caffeoylquinic acid

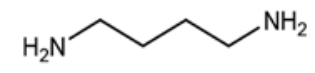<smiles>NCCCCNCCCN</smiles><smiles>O=C(O)/C=C/c1ccc(O)c(O)c1</smiles><smiles>O=C(/C=C/c1ccc(O)c(O)c1)O[C@@H]1C[C@@](O)(C(=O)O)C[C@H](O)[C@H]1O</smiles><smiles>O=C(/C=C/c1ccc(O)c(O)c1)O[C@H]1C[C@@](O)(C(=O)O)C[C@H](O)[C@H]1O</smiles>

Chicoric acid

Trans-caftaric acid

5-Caffeoylshikimic acid

Quercetin 3-O- $\beta$-D-glucoside

1,3-Dicaffeoylquinic acid
Lung cancer WI38, VA13, A549, HepG2 cells

Nasopharyngeal cancer KB cell, liver cancer Bel 7402 cell

Breast cancer MDA-MB-231 and T-47D cells

Bone cancer U-2 OS cell, cervical cancer HeLa cell, skin cancer Malme-3M cell, prostate cancer PC-3 and 293 cells Mammary duct carcinoma T-47D cell, promyelocytic leukemia HL-60 cell, liver carcinoma Hep-3B cell

Hepatoblastoma Hep-G2/2.2.15 cell Mouse preadipocyte: 3T3-L1 cell

Rat insulinoma INS-1E cell

Lung cancer (non-small cell): H1299 cells<smiles>O=C(/C=C/c1ccc(O)c(O)c1)OC(C(=O)O)[C@@H](OC(O)/C=C/c1ccc(O)c(O)c1)C(=O)O</smiles><smiles>O=C(/C=C/c1ccc(O)c(O)c1)O[C@H](C(=O)O)[C@@H](O)C(=O)O</smiles><smiles>O=C(OCc1ccc(O)c(O)c1)O[C@@H]1CC(C(=O)O)=C[C@H](O)[C@H]1O</smiles>

Mouse preadipocyte 3T3-L1 cells Cervical cancer HeLa cell line, breast cancer MCF-7 cells

Liver cancer HepG2 cells, cervical cancer HeLa cells

Rat skeletal myoblasts L6 cells

Liver cancer HepG2 cells, colon cancer

Caco-2 and 293 cells

Gastric BGC-82 cells

Colon cancer DLD-1 cells<smiles>O=C(/C=C/c1ccc(O)c(O)c1)O[C@H]1C[C@@](O)(C(=O)O)C[C@H](O)[C@H]1O</smiles>
6) 
Table I. Continued.

Phytochemicals

$$
\text { Chemical structure }
$$

Cell lines

(Refs.)

3,4-Dicaffeoylquinic acid<smiles>O=C(/C=C/c1ccc(O)c(O)c1)O[C@@H]1[C@@H](O)C[C@@](O)(C(=O)O)C[C@@H]1OC(=O)CCc1ccc(O)c(O)c1</smiles>

Quercetin-7-O-galactoside<smiles></smiles>

Quercetin-3-O-

(6"-O-malonyl)-glucoside<smiles>O=C(O)CC(=O)OC[C@H]1O[C@@H](Cc2c(-c3ccc(O)c(O)c3)oc3cc(O)cc(O)c3c2=O)[C@H](O)[C@H](O)[C@H]1O</smiles>

Cyanidin-3-O-galactoside<smiles>OC[C@H]1OC(Oc2cc3c(O)cc(O)cc3cc2-c2ccc(O)c(O)c2)[C@H](O)[C@@H](O)[C@@H]1O</smiles>

Cyanidin-3-O-glucoside<smiles>OC[C@H]1OC(Oc2cc3c(O)cc(O)cc3cc2-c2ccc(O)c(O)c2)[C@H](O)[C@@H](O)[C@@H]1O</smiles><smiles>O=c1cc(-c2ccc(O)cc2)oc2cc(OC3O[C@H](CO)[C@@H](O)[C@H](O)[C@H]3O)cc(O)c12</smiles>

Kaempferol-7-O-glucoside<smiles>O=c1c(O)c(-c2ccc(O)cc2)oc2cc(OC3O[C@H](CO)[C@@H](O)[C@H](O)[C@H]3O)cc(O)c12</smiles>

Delphinidin 3,5-di-O(6-O-malonyl- $\beta$-D-glucoside)

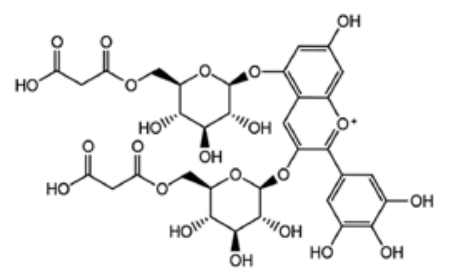

Malvidin-3-O-glucoside

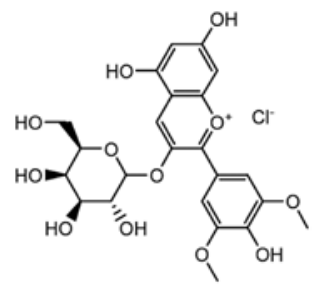

Stomach cancer: Kato III cells, colon cancer DLD-1 cells, promyelocytic leukemia HL-60 cells

Liver cancer HepG2 cells

Mouse neuroblastoma N2a cells

Not determined

Vulva carcinoma A431 cells

Lung carcinoma LLC cells

Pancreatic $\beta$-cell MIN6

Breast cancer HS578T and

MDA-MB-453 cells

Colon cancer HCT116 cells

Cervical cancer HeLa cells

Breast epithelial MCF10A cells

Breast cancer MCF-7 cells

Vulva carcinoma A431 cells 
Table I. Continued.

Phytochemicals
Pelargonidin-3-O-
monoglucuronide

Artesin/Artemisinin

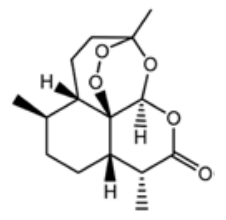

$\beta$-sitosterol

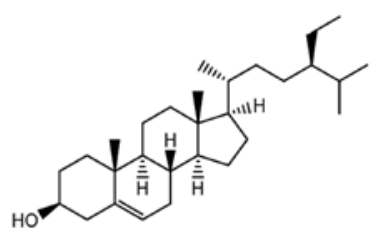

$\beta$-sitosterol-3-O-glucoside

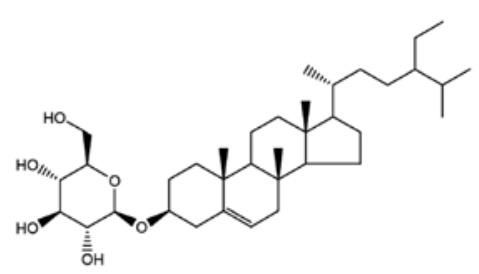

Campesterol

3-O-p-Coumaroyl quinic acid<smiles>O=C(/C=C/c1ccc(O)cc1)O[C@H]1C[C@@](O)(C(=O)O)C[C@H](O)[C@H]1O</smiles>

4-O-feruloylquinic acid

Usnic acid<smiles>CC(C)[C@H](C)CC[C@H](C)[C@]1(C)CC[C@H]2[C@H]3CC=C4C[C@@H](O)CC[C@]4(C)[C@H]3CC[C@H]21</smiles>

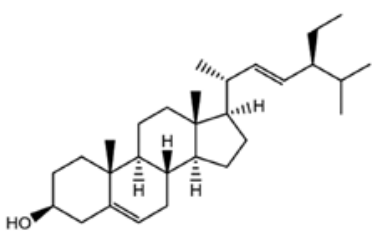<smiles>COc1cc(/C=C/C(=O)O[C@@H]2C[C@](O)(C(=O)O)C[C@H](O)[C@H]2O)ccc1O</smiles>

Colon cancer HCT116 and SW480 cells, leukemia HL-60 cells, breast cancer MCF-7 cells, melanoma KM, MJT3 cells, lung cancer (non-small cell) NSCLC cells, pancreas PANC-1 and MIAPaCa cells, glioma cancer U87MG and A172 cells<smiles>CC(=O)C1=C(O)C=C2Oc3c(C(C)=O)c(O)c(C)c(O)c3C2(C)C1=O</smiles>

Intrahepatic cholangiocarcinoma KKUM213 and RMCCA-1 cells, immortalized normal cholangiocytes MMNK-1 cells Breast cancer MCF-7 cells, cervical carcinoma Ca Ski cells, colon cancer HCT-116 cells

Chronic myelogenous leukemia

K-562 cells

Prostate cancer PC-3 cells, mouse preadipocyte $3 \mathrm{~T} 3 \mathrm{~L} 1$ cells

Colon cancer HT-29 cells

Breast cancer MCF-7 and MDA-MB-231 Cervical cancer HeLa cells Intrahepatic cholangiocarcinoma KKUM213 and RMCCA-1 cells, immortalized normal cholangiocytes MMNK-1

Breast cancer MCF-7 cells

Breast cancer MCF-7 cells

Leukemia HL-60 cells, liver cancer Hep G2 cells

Liver cancer HepG2 cells, breast cancer MCF-7 cells cells, lung cancer H1299 cells, prostate cancer LNCaP cells 
Table I. Continued.

\begin{tabular}{ll}
\hline Phytochemicals & Cell lines \\
\hline Inulin & Chemical structure
\end{tabular}

colon cancer cells (6-26\%) in vitro (17). A methanolic extract of $C$. intybus decreased the viability of breast cancer cells (SKBR3) in a time-dependent manner with an $\mathrm{IC}_{50}$ of 800,400 and $300 \mu \mathrm{g} / \mathrm{ml}$ at 24,48 , and $72 \mathrm{~h}$ treatment, respectively (18). The $n$-hexane extract of the aerial part demonstrated significant antiproliferative $(70 \%$ at $100 \mu \mathrm{g} / \mathrm{ml})$ as well as cytotoxic activity $(50.3 \%$ at $100 \mu \mathrm{g} / \mathrm{ml})$ against lymphocytic leukemia Jurkat cells (19). In another study, comparing the aerial part's methanolic extract of different plants on five cancer cell lines, C. intybus efficiently inhibited Jurkat cell growth $\left(\mathrm{IC}_{50}\right.$ of $138 \mu \mathrm{g} / \mathrm{ml}$ ), and moderately inhibited bladder carcinoma cell (Fen), and cervical epithelioid carcinoma cell (HeLa) growth (25\% decrease at $200 \mu \mathrm{g} / \mathrm{ml}$ ), but had no inhibitory effect on myelogenous leukemia cells (K562) (20). Here we describe C. intybus-derived phytochemicals with the reported antitumor, anticancer or antiproliferative properties.

Guaianolides. Sixteen guaianolides have been identified in C. intybus L. (Fig. 1A) (21-33) of which only two, 13-dihydro-8-deoxylactucin (jacquilenin) and 11,13-dihydrolactucopicrin, have chemotherapeutic properties. Both were isolated from a fractionated ethanol extract of leaves through a combination of column, thin layer chromatography, and HPLC (23). Leclercq (21) and Van Beek et al (27) also purified 11,13-dihydrolactucopicrin from $C$. intybus root methanolic extract. Jacquilenin showed inhibitory activity on the induction of ICAM-1 induced by IL- $1 \alpha$ and TNF- $\alpha$ in alveolar basal epithelial adenocarcinoma cells (A549; $\mathrm{IC}_{50}$ values of 16.1 and $20.1 \mu \mathrm{M}$ for IL- $1 \alpha$ and TNF- $\alpha$, respectively) and cytotoxicity against human lung fibroblast cells (WI38 and VA13; IC $_{50}$ values of 2.7 and $8.5 \mu \mathrm{M}$, respectively) and hepatocellular carcinoma cells (HepG2; $\mathrm{IC}_{50}$ of $25 \mu \mathrm{M}$ ) in vitro (34). Isolated 11,13-dihydrolactucopicrin from Mulgedium tatarica by Ren et al (35) demonstrated antitumor activity in human nasopharyngeal cancer cells (KB; $\mathrm{IC}_{50}$ of $\left.22 \mu \mathrm{M}\right)$ and human liver cancer cells (Bel 7402; $\mathrm{IC}_{50}$ of $30 \mu \mathrm{M}$ ).

Structural activity relationship (SAR) studies by Ren et al (35) revealed that the position 8 ester group ( $\gamma$-butyrolactone) and the methylene group at exocyclic position $11(\alpha)$ (Fig. 1A) play a major role in antitumor activities of lactucin-like guaianolides (35). $\alpha$-methylene- $\gamma$-lactone, the '-enone' or unsaturated carbonyl $\left(\mathrm{O}=\mathrm{C}-\mathrm{C}=\mathrm{CH}_{2}\right)$ system was found to increase the toxicity towards tumor cells (36). Both reported chemoprotective guaianolides in $C$. intybus (Jacquilenin and 11,13-dihydrolactucopicrin) share these features, confirming the structural basis of the activity. Further studies have shown that this structural motif works as a monofunctional alkylate and selectively deactivates the p65 dimer of
$\mathrm{NF}-\kappa \mathrm{B}$ preventing NF- $\kappa \mathrm{B}$ transcription in treated cells $(37,38)$. This targeting of specific signaling pathways is also observed with other metabolites.

Polyacetylenes. C. intybus contains five polyacetylenes (Fig. 1B) $(21,23,26,31,39,40)$. Putrescine and spermidine extracted from leaves by Krebsky et al (39) show potency as antitumor agents (41-45). Putrescine is the precursor of spermidine, and both are ubiquitous constituents of eukaryotic cells (41). Their cellular concentration is associated with the effectiveness of many anticancer therapeutics. The in vitro antitumor activity of putrescine has been demonstrated in breast cancer cell line MDA-MB-231 ( IC $_{50}$ of $\left.110 \mu \mathrm{g} / \mathrm{ml}\right)(43,45)$, and it showed antiproliferative effect on T-47D breast cancer cells $(0.1 \mathrm{mM})(44)$. Inhibition of proliferation of human alveolar basal epithelial adenocarcinoma cells (A549; $\mathrm{IC}_{50}$ of $4.54 \mu \mathrm{g} / \mathrm{ml}$ ), prostate adenocarcinoma cells (LNCaP; $\mathrm{IC}_{50}$ of $1.1 \mu \mathrm{g} / \mathrm{ml}$ ), breast epithelial cancer cells (T47D; $\mathrm{IC}_{50}$ of $0.97 \mu \mathrm{g} / \mathrm{ml}$ ), bone osteosarcoma cells (U2-OS, $\mathrm{IC}_{50}$ of $4.47 \mu \mathrm{g} / \mathrm{ml}$ ), HeLa cells, skin fibroblast cells (Malme-3M), prostate cancer cells (PC-3) and embryonic kidney cells (HEK-293) was demonstrated by Cheng et al (42). Putrescine and spermidine were found to be able to cross the cell membrane by a single unique channel or by separate ones (41). The higher lipophilicity of polyacetylene compounds facilitates plasma membrane penetration but often lowers their bioavailability in vivo (36). A comparison between different plant-derived polyacetylenes by Kinjo et al (46) suggested an inverse relationship of the presence of bulky side chains (hydroxy, methoxy, amino or other groups) with activity and effectiveness. The authors also found that $C$. intybus polyacetylenes were more effective against MK-1 cells than HeLa and B16F10 cells, and their antiproliferative effects were more profound than other chemoprotective characteristics (46). In estrogen-responsive breast cancer cells (ZR-75-1), both putrescine and spermidine were internalized via the same or similar transporter and both $\mathrm{V}_{\max }$ was rapidly upregulated by estrogens and insulin (47). The presence of positively charged primary and secondary amino groups (at physiologic $\mathrm{pH}$ ) and hydrophobic methylene bridging groups indicate their capability of acting as ligands at multiple locations of DNA, RNA, proteins, phospholipids and nucleotide triphosphate. Few of these connections are electrostatic and replaced easily by inorganic cations. The rest are specific to the extent of the aliphatic carbon chain (Fig. 1B) $(48,49)$. Although polyamines are critical for cell proliferation, their high concentration can lead to interruption in transcriptions and protein-protein interactions, and thus inhibition of tumor growth. 

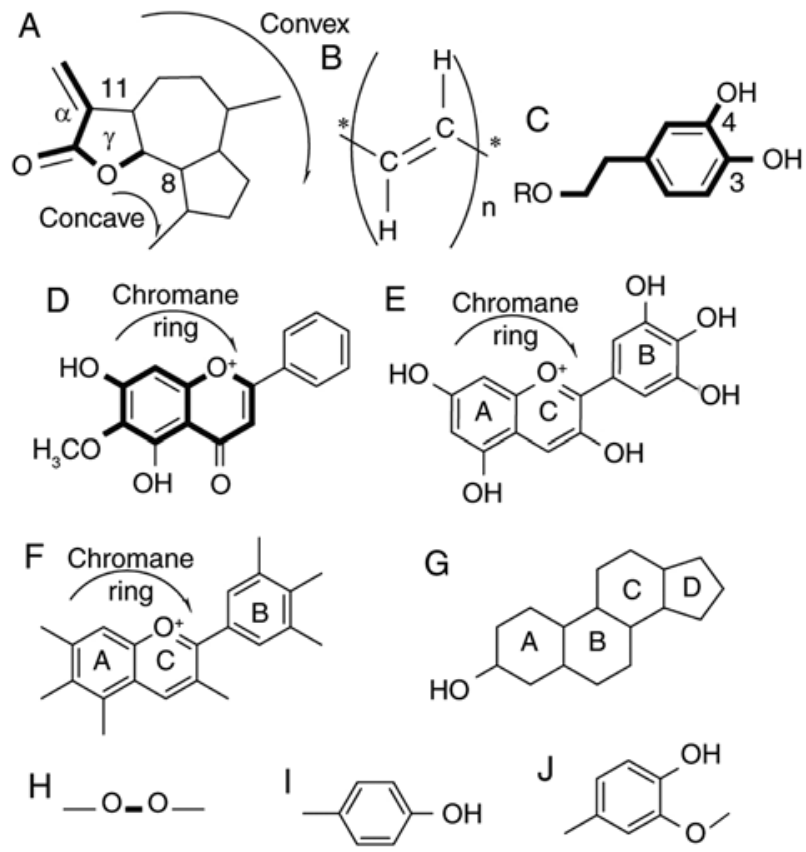

Figure 1. Chemical groups and structural motifs of $C$. intybus-derived phytochemicals. Figures show the primary structural features of (A) guaianolides, (B) polyacetylene, (C) 3,4-dihydroxyphenethyl, (D) 6-methoxyflavone (E) delphinidin, (F) anthocyanin, (G) phytosterol/sterol, (H) peroxide, (I) phenol and (J) 4-hydroxy-3-methoxyphenyl.

3,4-Dihydroxyphenethyl. Phytometabolites containing a 3,4-dihydroxyphenethyl group (Fig. 1C) are the most frequent type of metabolites found in C. intybus. Furthermore, 19 of the 28 phytometabolites $(5,24,50-52)$ were found to exhibit antitumor properties. Major members of this group include hydroxycinnamic acids, quercetins, kaempferols, and cyanidins, among others.

Among the hydroxycinnamic acids, chlorogenic acid and caffeic acid have both been extracted from $C$. intybus hairy root (Agrobacterium rhizogenes-induced) culture (24) and leaves [MeOH-HCOOH (99:1, v/v) extract] $(5,24,51)$. Caffeic acid is highly effective against human promyelocytic leukemia cells (HL-60; 90\% inhibition at $10 \mu \mathrm{M})(53,54)$, mammary duct carcinoma cells (T-47D; $\mathrm{IC}_{50}$ of $\left.2.17 \times 10^{-9} \mathrm{M}\right)(55)$ and liver carcinoma cells (Hep3B) (56). It also demonstrated high antioxidant as well as anti-inflammatory activity (57). Caffeic acid was found to be moderately effective against epidermal DNA synthesis, epidermal ornithine decarboxylase activity, and skin tumors induced by $12-O$-tetradecanoylphorbol-13-acetate (TPA; $\mathrm{IC}_{50}$ of $72.3 \mu \mathrm{M}$ ) (58). Chlorogenic acid showed in vivo inhibitory effects on 8-hydroxydeoxyguanosine (8-OH-dG) formation induced by lipid peroxides in 4-nitroquinoline-1-oxide (an oxygen radical-forming carcinogen)-treated animal tongue, but not the endogenous 8-OH-dG (59). Chlorogenic acid was found to protect against environmental carcinogen-induced carcinogenesis (60). An in vitro study also demonstrated the antiviral potency of chlorogenic acid in human hepatoblastoma cells (Hep-G2.2.15; $\left.\mathrm{IC}_{50}>1,000 \mu \mathrm{M}\right)(61)$, antitumor potency against mouse preadipocyte cells (3T3-L1; $\mathrm{IC}_{50}$ of $\left.72.3 \mu \mathrm{M}\right)(62,63)$, and increased insulin secretion in rat insulinoma cells (INS-1E) (64). Caffeic acid contains both phenolic (Fig. 1I) and acrylic functional groups. The amount of absorption in the small intestine (most of the caffeic acid and one-third of the chlorogenic acid) indicates that most chlorogenic acid reaches the colon and only a fraction enters the blood circulation (65).

5-Caffeoylquinic acid, 5-caffeoylshikimic acid, di-caffeoyl tartaric acid (also called chicoric acid), trans-caftaric acid and 4-O-feruloylquinic acid have been purified from $C$. intybus leave $\mathrm{MeOH}-\mathrm{HCOOH}$ (99:1, v/v) extract (5). A previous study showed that 5-caffeoylquinic acid inhibited non-small cell lung cancer cell (H1299) invasion (66). Trans-caftaric acid has antioxidant properties and protects against DNA damage caused by ROS. A trans-caftaric acid rich extract was found to demonstrate cytotoxicity in HepG2 (liver cancer cells; $\mathrm{IC}_{50}$ of $50 \pm 12 \mu \mathrm{g} / \mathrm{ml}$ ) and HeLa cells $\left(\mathrm{IC}_{50}\right.$ of $32 \pm 16 \mu \mathrm{g} / \mathrm{ml}$ ) (67). 5-Caffeoylshikimic acid displayed antioxidant and antitumor properties on rat skeletal myoblast (L6; $\mathrm{IC}_{50}$ of $90 \mu \mathrm{g} / \mathrm{ml}$ ) cells (68). A 4-O-feruloylquinic acid rich extract from Oplopanax horridus (Sm.) Miq. exhibited anti-proliferative effects against human colon adenocarcinoma cells (HT-29; $56.5 \%$ inhibition with a $0.2 \mathrm{mg} / \mathrm{ml}$ extract) (69). Chicoric acid, in synergy with luteolin was found to act as an anti-oxidant and anti-inflammatory agent in mouse macrophage cells (RAW 264.7; luteolin:chicoric acid $=1: 1,1: 2,1: 4$ where $\mathrm{IC}_{50}$ of luteolin was $11.6,9.8$ and $9.8 \mu \mathrm{M}$, respectively) (70). Chicoric acid caused the apoptosis of mouse 3T3-L1 preadipocytes (71) and displayed antiproliferative activity in MCF-7 cells but promoted the proliferation of the HeLa cell line (72).

Among the eight quercetins (a polyphenolic flavonoid compound) found in $C$. intybus, six were found to inhibit the growth of several malignant tumors (73). Both leaf and flower extracts of $C$. intybus contain quercetin 3-O- $\beta$-D-glucoside $(52,74)$, which promoted the apoptosis of human gastric carcinoma cells (BGC-823; $12.1 \pm 0.03 \%$ inhibition at $100 \mu \mathrm{M})(75)$, HepG2 $\left(\mathrm{IC}_{50}\right.$ of $150 \mu \mathrm{g} / \mathrm{ml})$, Caco-2 $\left(\mathrm{IC}_{50}\right.$ of $\left.79 \mu \mathrm{g} / \mathrm{ml}\right)$, HEK-293 $\left(\mathrm{IC}_{50}\right.$ of $186 \mu \mathrm{g} / \mathrm{ml})$ cells $(76)$.Quercetin-7-O-galactoside, quercetin-3-O(6"-O-malonyl)-glucoside, quercetin-7-O-glucoside, quercetin7-O-glucuronide, quercetin-7-O-(6"-O-acetyl)-glucoside, quercetin-7-O-p-coumaroylglucoside, and quercetin-3-O-glucuronide-7-O-(6"-O-malonyl)-glucoside have been extracted from the leaf (5). Most of the compounds containing 3,4-dihydroxyphenethyl are potent antioxidant and specific inhibitors of NF- $\mathrm{BB}$ and Akt. The functionality of quercetin depends largely on the positioning of glycosylation and derivatization of a sugar molecule (77). With the different glycation sites, glucoside derivatives of quercetin show ex-vivo 2,2-diphenyl-1-picrylhydrazyl (DPPH) and 3-ethylbenzothiazoline-6-sulphonic acid (ABTS) free radical scavenging capacity at a varying degree (77). Quercetin isomers with a pentyl group in 7 positions were found to significantly inhibit CT26 cell proliferation (78). Quercetin hydrate demonstrated cytotoxicity against a human liver cancer cell line (HepG2) (73) and demonstrated antitumor activity against $\mathrm{N} 2 \mathrm{a}$, a mouse neuroblastoma cell line whereas C3 quercetin showed excellent antioxidant property in ex-vivo trials $(77,79)$.

Leaf extract from $C$. intybus also yields phytochemicals such as 1,3-dicaffeoylquinic acid (5), 3,4-dicaffeoylquinic acid (5), cyanidin-3-O-galactoside (5) and cyanidin-3-Oglucoside (50). 1,3-Dicaffeoylquinic acid was found to exhibit antioxidant properties and inhibit oxidative damage created 
by $\mathrm{FeSO}_{4}$ and AAPH [2,20-azobis(2-amidinopropane) dihydrochloride] and scavenge ROS. 1,3-Dicaffeoylquinic acid is required in low concentrations than other known antioxidants (80). 3,4-Dicaffeoylquinic acid inhibited the growth of Kato III (human stomach cancer; 20-40\% inhibition at 100-500 $\mu \mathrm{M})$, DLD-1 (20-40\% inhibition at $1,000 \mu \mathrm{M})(53)$ and HL-60 (40-90\% inhibition at 1,000 $\mu \mathrm{M})$ cells in vitro (53). Cyanidin-3-O-glucoside inhibited tumor cell growth, induced apoptosis in vitro, and suppressed tumor growth in vivo (81). It protected MIN6 (pancreatic $\beta$-cells; cell viability $86.6 \%$ at $200 \mu \mathrm{g} / \mathrm{ml}$ ) cells against apoptosis induced by oxidative stress (82), and showed dose-dependent growth inhibition on tumors derived from HS578T, LLC (Lewis lung carcinoma) (81) and MDA-MB-453 (human breast cancer) cells in a xenografted animal model (83). Cyanidin-3-O-galactoside inhibited the development of the A431 cell line (human vulva carcinoma; $\left.\mathrm{IC}_{50}>100 \mu \mathrm{M}\right)$ (84).

6-Methoxyflavone. The second largest group of phytochemicals is the 6-methoxyflavone (also known as 6-hydroxyflavone) group (Fig. 1D), with 18 members $(5,52)$. Six have shown antitumor properties. Among them, apigenin-7-O-glucoside, kaempferol-7-O-glucoside, isorhamnetin-7-O-glucoside, and isorhamnetin-7-O-glucuronide have been isolated from leaf extract (5). Apigenin-7-O-glucoside was found to be cytotoxic against colon cancer cells (HCT116) (85), androgen-refractory PC-3 cells, and other cancer cell lines (86). Interestingly, there are 11 known isomers of kaempferols in C. intybus, but only kaempferol-7-O-glucoside was found to induce G2/M mitotic phase arrest and cell death in a p53-independent manner in HeLa cells (87). Among the three derivatives of isorhamnetin (a 6-O-methylated flavanol) (5), only C7 glucoside and glucuronide isomers were demonstrated to exert antitumor properties $(88,89)$. In lipopolysaccharide-challenged mouse Abelson murine leukemia virus-transformed macrophage cells (RAW264.7), isorhamnetin-3-O-glucuronide increased heme-oxygenase- 1 but suppressed p38 and c-Jun N-terminal kinase (JNK) activation (89). This indicates that derivatives of isorhamnetin from C. intybus can be modified to generate chemoprotective agents. Among four delphinidins isolated by Nørbaek et al (52) from $C$. intybus flower extract, only delphinidin 3,5-di-O-(6-O-malonyl- $\beta$-D-glucoside) exerted an antitumor effect, and the mono sugar substitute was effective against breast epithelial cells (MCF10A) (90).

Another study showed that 6-methoxyflavone (Fig. 1D) was associated with HeLa cell growth inhibition (46). However, the precise mechanism is not yet known.

Phytosterol.C. intybus contains four phytosterols (Fig. 1G), all with chemoprotective properties. Campesterol and stigmasterol are two of the major phytosterols found in the leaves (39). Campesterol shows antitumor and antiproliferative activity against HepG2 and MCF-7 cells (91). Stigmasterol was found to exhibit antitumor activity against EAC in swiss albino mice (92). The cytotoxicity of stigmasterol was demonstrated by Kangsamaksin et al (93) in KKU-M2123, RMCCA-1 and MMNK-1 cell lines; by Syed Abdul Rahman et al (94) in MCF-7, CaSki (cervical carcinoma), and HCT-116 cell lines; and by Dutra et al (95) in a chronic myelogenous leukemia cell line (K-562). In vivo, stigmasterol showed antitumor efficacy against a 1,3-dimethylbutylamine-induced skin carcinoma mouse model (96) and antioxidant activity against EAC in swiss albino mice (92). $\beta$-sitosterol is the most abundant phytosterol, present in leaves (39), roots (97), and total areal part extract (26). $\beta$-sitosterol increased the activity of antioxidant enzymes, glutathione peroxidase, and superoxide dismutase in cultured macrophage cells with phorbol 12-myristate 13-acetate-induced oxidative stress. This indicates that phytosterols can protect cells from ROS induced damage (98). In in vitro experiments, $\beta$-sitosterol was found to be cytotoxic to HeLa (99), intrahepatic cholangiocarcinoma (KKU-M213, RMCCA-1) (93), immortalized normal cholangiocyte (MMNK-1) (93), and breast cancer cells (MCF-7) $(100,101)$. In in vivo experiments, $\beta$-sitosterol reduced tumor growth in 17 $\beta$-estradiol-treated mice (98). A nonmalignant enlargement of the prostate known as benign prostatic hyperplasia (BPH) was reduced by $\beta$-sitosterol treatment (102). $\beta$-sitosterol was also found to inhibit the proliferation and thus reduce the viability of mouse fibrosarcoma (98). $\beta$-sitosterol-3-O-glucoside from the areal part of $C$. intybus isolated by Satmbekova et al (26) exerted an anticancer effect against three cancer cell lines, MCF-7, HL-60 and HepG2 $(91,103)$.

The phytosterols containing an unsaturated ring structure (Fig. 1G) are susceptible to oxidation under certain conditions. Comparison of the corresponding phytosterol and cholesterol oxidation-products (POP) in four cell lines demonstrated that phytosterol induces oxidation-independent apoptosis (104), which is in contrast to a previous report by O'Callaghan et al (105). These authors suggested that POP induced apoptosis by high oxidative stress, glutathione reduction, mitochondrial dysregulation and elevated caspase activity (105). From Table I, we can see that phytosterols show specificity towards fatty tissue-related cancer lines such as those derived from breast, cholangiocyte, and cervix cancer.

Delphinidin. All four delphinidins (Fig. 1E) found in C. intybus are di-glucoside isomers, and none has antitumor properties. However, mono-glucoside substitutes of delphinidins are cytotoxic (88). Delphinidin-3-glucoside was found to be chemopreventive against breast epithelial cells (MCF10A) (90). Derivatives of $C$. intybus derived delphinidins can serve as potent chemoprotective agents.

Anthocyanins. The aglycons are the richest anthocyanins (Fig. 1F) found in food. Cyanidin and delphinidin were found to inhibit the growth of human tumor cells in vitro in small quantities (84). C. intybus fresh leaf extract $[\mathrm{MeOH}-\mathrm{HCOOH}$ $(99: 1, \mathrm{v} / \mathrm{v})]$ contains malvidin-3-O-glucoside and pelargonidin-3-O-monoglucuronide (5). Malvidin-3-O-glucoside was demonstrated to have antitumor activity against MCF-7 (106) and A431 (84) cell lines. Pelargonidin-3-O-monoglucuronide increased the concentration of IL- 6 and monocytes in vitro, affecting tumor prognosis of THP-1 cells (human monocytic leukemia) (107). Its glucoside derivative, pelargonidin-3-O-glucoside, acts as an anti-inflammatory agent (108).

Seong et al (109) demonstrated that delphinidin treatment induced hypoacetylation of histone acetyltransferase (HAT) and inhibited p65 acetylation in a human rheumatoid fibroblast-like synoviocyte cell line (MH7A) (Fig. 4). TNF- $\alpha$ stimulation increases NF- $\mathrm{KB}$ expression, and thus promotes the 
functions of NF-kB target genes (109). Delphinidin also inhibited the release of pro-inflammatory cytokines IL- 6 and TNF- $\alpha$ in lipopolysaccharide-treated Jurkat T lymphocytes (109). The chemotherapeutic property of delphinidin-3-glucoside against MCF10A cells is related to downregulation of non-coding RNA (lncRNA) and HOX transcript antisense RNA (HOTAIR) expression (90). Pelargonidin-3-O-monoglucuronide treatment was found to increase the IL- 6 and monocytes concentration (107). Bioactivity of these compounds is related to the presence of hydroxyl group in position 3 of the $\mathrm{C}$ ring and 3, 4, 5 in the $\mathrm{B}$ ring (Fig. 1E and $\mathrm{F}$ ) which corresponds to the report by Wang and Stoner (110), showing that methylation on these positions decreases the activity.

4-Hydroxy-3-methoxyphenyl. 4-O-Feruloylquinic acid is one of the two 4-hydroxy-3-methoxyphenyl groups (Fig. 1J) containing phytochemicals found in C. intybus. It was demonstrated to scavenge oxygen radical absorbance capacity (ORAC) and DPPH radical in an in vitro experiment (69).

Other phytochemicals. Researchers also identified several other types of phytochemicals in C. intybus. Artesin (also known as artemisinin, an antimalarial agent) was identified in the root extract fraction by Kisiel and Zielińska (23). Its antitumor property has been well studied (111-115). The derivatives of artesin have in vivo chemosensitizing effects in breast, lung, pancreas, and glioma cancer cells (112). Artesin and its derivatives activated by heme [Fe (II)] showed selective inhibition of colon (HCT116, SE480), leukemia (HL-60), breast (MCF-7), melanoma (KM, MJT3), lung (NSCLC), pancreas (PANC-1, MIAPaCa), and glioma (U87MG, A172) cancer cell lines (113-115). In primary cancer culture, cell lines and xenograft models, artesin inhibited tumor proliferation, metastasis, and angiogenesis (114). Several antitumor mechanisms of artesin have been proposed, including apoptosis, cell cycle arrest at G0/G1, and oxidative stress (111). Rapidly proliferating cancer cells express more transferrin receptors on their cell surface, leading to higher iron uptake. Artesin/artemisinin is the only phytochemical found in C. intybus with a peroxide bridge (Fig. 1H). When artesin binds to Fe (II), the endoperoxide bridge (Fig. $1 \mathrm{H})$ is disrupted, resulting in the production of toxic C-4 and seco-C-4 free radicals that destroy tumor cells (Fig. 2) (36).

3-O-p-Coumaroyl quinic acid was isolated by Nørbaek et al (52) from an extract of $C$. intybus flower. 3-O-p-Coumaroyl quinic acid was demonstrated to show antiproliferative activity against PC-3 and undifferentiated non-cancerous 3T3L1 fibroblast cells (116). Usnic acid purified from the areal part extracts (26) was reported to exhibit chemoprotective effects against the wild-type p53 MCF-7 cell line along with a breast cancer cell line with non-functional p53 (MDA-MB-231), lung cancer cell line (H1299) (117) and prostate cancer cell line (LNCaP) (118). Mechanistically, (+)-usnic acid treatment dose-dependently decreases $\beta$-catenin-mediated transfection grade $\mathrm{T}$-cell factor reporter plasmid activity and KAI1 COOH-terminal interacting tetraspanin-mediated AP-1 activity. In addition, (+)-usnic acid decreases the mRNA levels of CD44 (a cell-surface glycoprotein), cyclin D1 (a mitotic regulatory protein) and c-myc (a transcription factor). These are the downstream target genes of both $\beta$-catenin/LEF and
c-jun/AP-1. Furthermore, (+)-usnic acid treatment was found to decrease the functionality of Rac1 and RhoA. Interestingly, cotreatment of (+)-usnic acid and cetuximab showed higher inhibition of cell proliferation then the single cetuximab treatment. These results indicate the potential antitumor activity and metastasis inhibitory quality of (+)-usnic acid and suggest (+)-usnic acid can be used for anticancer therapy with distinct mechanisms of action (119).

C. intybus root is a major source of inulin, a heterogeneous collection of fructose polymers primarily used as a prebiotic (120). The chemoprotective property of inulin has been confirmed in colon cancer colonic preneoplastic aberrant crypt foci inhibition (121). Its antitumor property was also demonstrated on transplantable liver tumor cells (TLT) and mouse mammary carcinoma cells (EMT6) (121-123). Low fermentation of inulin indicates its possibility to reach the distal part of the intestine (124). Inulin extracted from Cichorium endivia $\mathrm{L}$. (a related species) was found to reduce the occurrence of intestinal tumors in an $\mathrm{APC}^{\mathrm{MIN}}$ mouse model (121).

\section{Molecular mechanisms}

SARs. Most of the phytochemicals identified in C. intybus appear to show potent activity as inhibitors in specific tumor cell lines; only a few phytochemicals work on all cell lines. A screening study of anti-proliferative activity revealed the specificity of purified $C$. intybus phytochemicals against different cancerous cell lines. Kinjo et al (46) and other researchers showed that groups of phytochemicals had specificity towards specific cancer cell lines (listed in Table II). In general, polyacetylenes are potent antiproliferative agents against MK-1 cells, and compounds with 3,4-dihydroxyphenethyl against B16F10 cells, and some 6-methoxyflavone derivatives and 8-hydroxy furanocoumarins against HeLa cells are potent anti-proliferative agents (46). This indicates that the structural features of these phytochemicals directly interact with the cytochemistry of specific cancerous cells. The biological activities of the guaianolides, 6-hydroxyflavone, and anthocyanin depend broadly on the following: i) reactivity of alkylation center; ii) lipophilicity of the side chain; iii) electronic features and molecular genomics (36).

Similarly, every phytochemical has its own conserved structural features responsible for bioactivity. The antitumor property of flavonoids is partly due to their ability to counteract fatty acid synthase (FASN). Cancerous cells have an elevated metabolic rate compared with healthy cells, which enables cancer cells to grow and proliferate at a faster rate (18). Rapid cell division often leaves trails of both biochemically and structurally irregular cells. FASN is overexpressed in cancerous tissues of the breast, prostate, and colon (18), and is also related to angiogenesis and metastasis (125); therefore, FASN is recognized as an important antitumor target.

Previous studies have reported that phytochemicals of C. intybus exert antitumor effects by affecting many critical overactive signaling pathways in cancerous cells, such as NF- $\kappa \mathrm{B}, \mathrm{p} 53$-associated cell cycle, and CYP-mediated inactivation. The various effects of these phytochemicals confer the advantages to effectively target more than one cell type, which is often encountered during metastasis. 


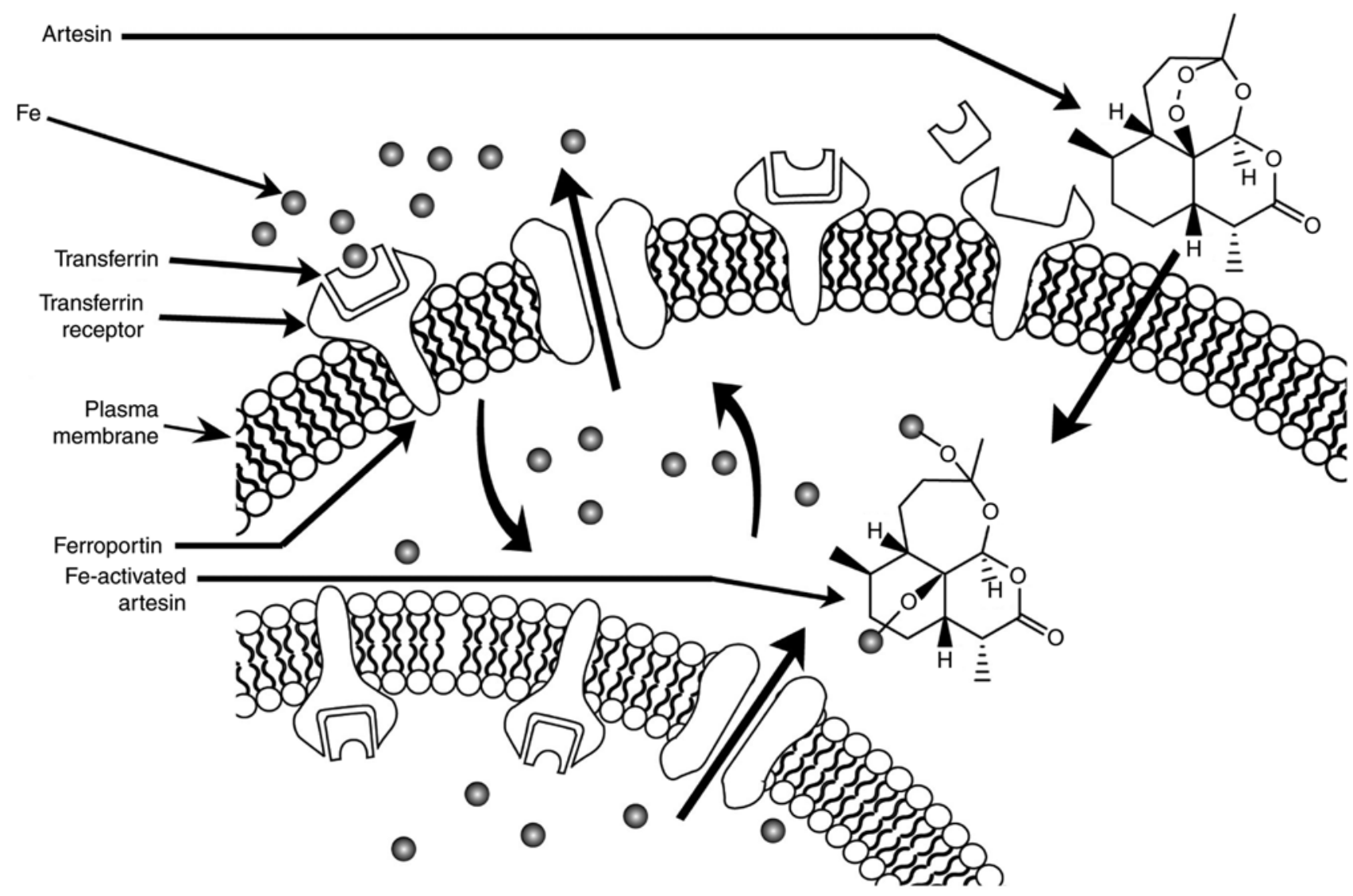

Figure 2. Iron-dependent free radical generation by artesin. Breaking of the endoperoxide bridge of artesin and binding of cytoplasmic Fe (II) to its C-4 and seco-C-4. This creates free radical-activated toxic artesin that destroys tumor cells.

Inhibition of $N F-\kappa B$. The nuclear factor- $\kappa \mathrm{B}(\mathrm{NF}-\kappa \mathrm{B})$ transcription factor plays a critical role in cell development, growth, and survival as well as various biological processes, including immune response and inflammation. Numerous inflammatory stimuli such as growth factors and infectious microbes lead to NF- $\kappa \mathrm{B}$ activation (126). Activated NF- $\kappa \mathrm{B}$ in turn regulates the expression of genes governing cell growth, proliferation, survival, and apoptosis as well as immune responses, stress responses, embryogenesis, and development of a variety of stimuli (127). Abnormal NF- $\mathrm{BB}$ activation causes various autoimmune, inflammatory, and malignant disorders such as rheumatoid arthritis, atherosclerosis, inflammatory bowel diseases, multiple sclerosis, and malignant tumors. Thus, inhibition of NF- $\mathrm{\kappa B}$ signaling is a key target in the treatment of tumors and inflammatory diseases (127). The mammalian NF- $\kappa B$ family is composed of five members that form various dimeric complexes. Among these complexes, the p50/65 heterodimer is most abundant. Overexpression of this complex in cancer cells leads to the aberrant levels of cell cycle control factors. Several phytochemicals of $C$. intybus disrupt different stages of NF- $\mathrm{KB}$ activation and NF- $\kappa \mathrm{B}-\mathrm{DNA}$ complex formation. Guaianolides, germacranolides, heliangolides, pseudo guaianolides, hypocretenolides, and eudesmanolides are collectively classified as sesquiterpene lactones. Sesquiterpene lactones bind to the p65 dimer in the NF- $\kappa \mathrm{B}$ transcription factor to prevent NF- $\mathrm{BB}-\mathrm{DNA}$ binding (Fig. 3). The three-dimensional structure created by Arg 33, Arg 35, Tyr 36, Cys 38, Glu 39 and Arg 187 is crucial for DNA binding of the p65 dimer. Rüngeler et al (37) proposed that lactucin creates cross linkage of Cys 38 to Cys 120 in the p65 molecule (Fig. 3) that changes the DNA binding motif structure and affects subsequent transcription, eventually leading to apoptosis. This mechanism was further demonstrated in a computer-generated model by García-Piñeres et al (38). The authors showed the change in native confirmation of p65 caused by a sesquiterpene lactone that led to its inability of NF-kB-DNA complex formation.

Búfalo et al (57) demonstrated that caffeic acid mediated cell viability independent anti-inflammatory activity and proposed that caffeic acid exhibited an inhibitory effect in lipopolysaccharide (LPS)-induced NF- $\kappa \mathrm{B}$ activity. The chemoprotective effect of chlorogenic acid may be accomplished through its increase of cellular antioxidant enzymes and suppression of ROS-mediated NF- $\mathrm{KB}$, activator protein 1 (AP-1), and mitogen-activated protein kinase (MAPK) activation (60). 5-Caffeoylquinic acid inactivates ribosomal protein S6 kinase (p70S6K) and protein kinase B (PKB/Akt) activity and thus affects multiple cellular processes and signal transduction pathways in cancerous cells. Another study showed that 1,3-dicaffeoylquinic acid scavenged hydroxyl radical and superoxide radicals as measured by electron spin resonance (ESR) (80). Chicoric acid was found to exert its anti-inflammatory function by halting the phosphorylation of NF- $\kappa B$ (70). Upon co-treatment with luteolin, chicoric acid simultaneously reduced the concentration of nitric oxide and prostaglandin E2 (PGE2) in cells and also inhibited inducible 
A

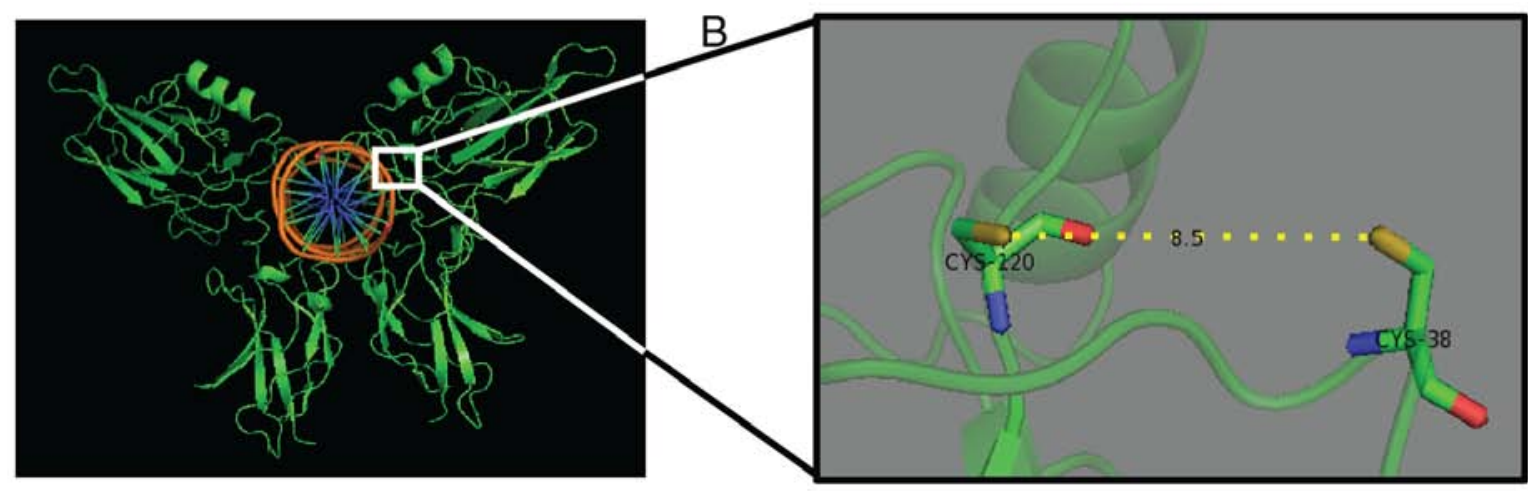

C

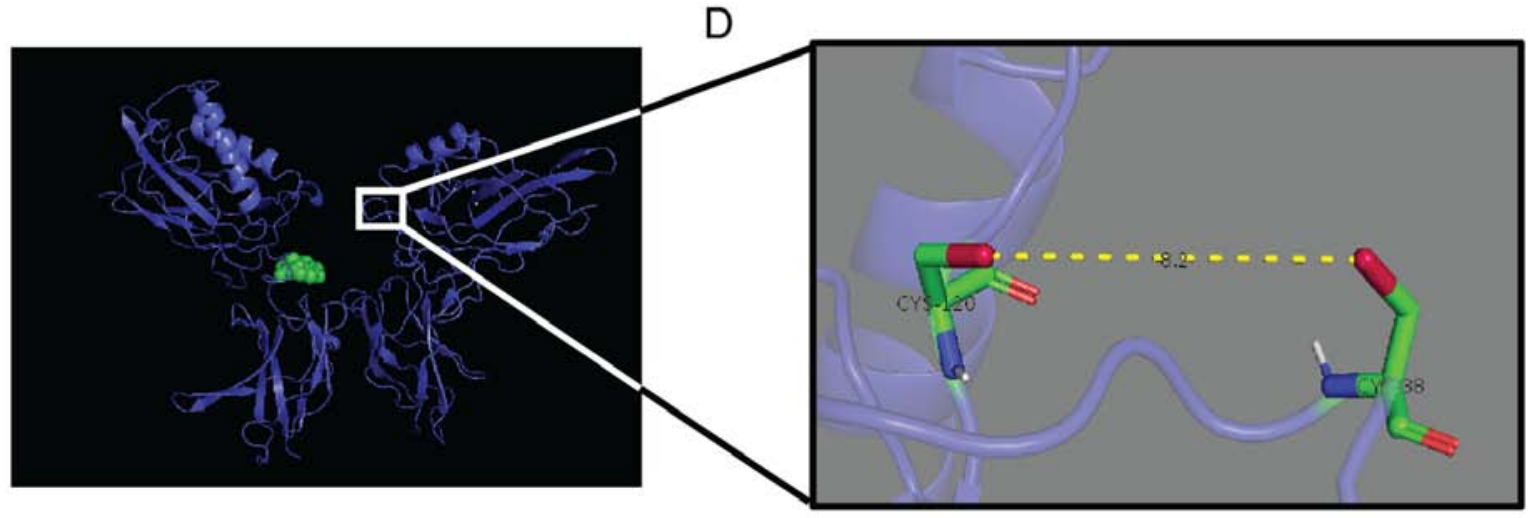

Figure 3. Mouse NF- $\kappa B$ p65 homodimer. Figures show (A) DNA (orange)-bound NF- $\kappa B$ p65 (green) homodimer (PDB ID: 1RAM), (B) distance between Cys38 and Cys120 of NF-kB p65 homodimer at the native state, (C) lactucin (green)-bound NF-kB p65 homodimer (blue), and (D) distance between Cys38 and Cys120 of NF-kB p65 homodimer at the lactucin bound state.

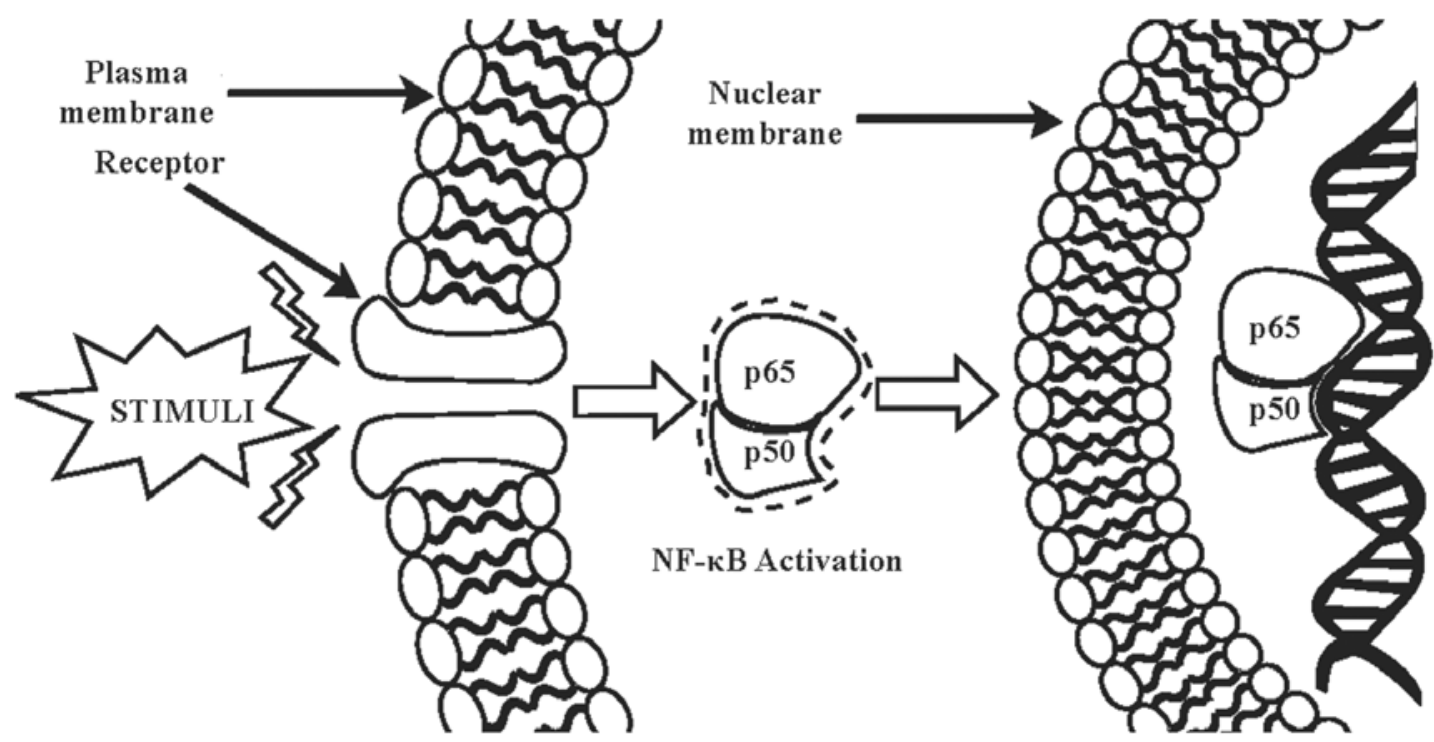

Figure 4. Activation and NF-kB-DNA binding.

nitric oxide synthase (iNOS) and cyclooxygenase-2 (COX-2) expression (70).

p53 associated cell cycle inhibition. Genomic instability is one of the fundamental cause of tumor development. p53, commonly known as TP53 or tumor protein 53 , is a cell cycle regulatory protein that functions as a tumor suppressor. p53 responds to DNA damage and other types of genotoxic stress and functions to maintain genomic stability. The close involvement of p53 in maintaining genomic stability is why nearly half of human cancers lack functional p53. In the other half of cancers, the p53-independent regulatory mechanism is absent or the p53-dependent pathway gets disabled at different key points. For instance, the p53 inhibitor MDM2 is overexpressed 


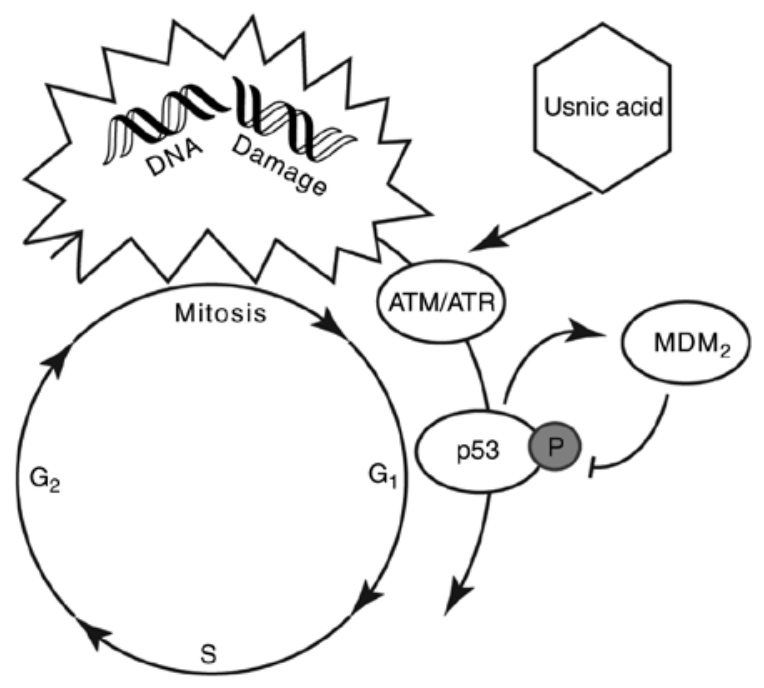

Figure 5. Cell cycle arrest at G1 phase by p53. Ataxia telangiectasia mutase (ATM)- or reductase (ATR)-mediated phosphorylation of p53, leading to G1 cell cycle arrest.

in tumors that lack p53 gene mutation. p53 is a crucial component of a complex network of signaling pathways. However, other components of this pathway can be alternately targeted for inactivation in cancer. $C$. intybus extract, in particular, usnic acid, was found to induce levels of factors such as ataxia telangiectasia mutase (ATM) or reductase (ATR) that phosphorylates p53 at the MDM2 binding site (Fig. 5) (117). However, kaempferol-7-O-glucoside arrests cell division in a p53-independent manner (87).

CYP-mediated inactivation. Cytochrome $\mathrm{P} 450$ enzymes (CYPs) are a superfamily of enzymes that are important for the metabolism of endobiotics and xenobiotics (128). Rodriguez-Antona and Ingelman-Sundberg (129) described the pharmacogenetics of CYPs in cancer formation and treatment. CYPs are linked to the metabolic activation of numerous pre-carcinogens and participate in the activation and inactivation of antitumor drugs (129). Hepatic CYP expression and activity can be upregulated or downregulated by bioactive phytochemicals (130). Direct foddering of dried $C$. intybus roots to pigs resulted in increased activities of CYP1A2 and CYP2A, which in turn reduced the skatole concentration in plasma and fat (128), reducing the chances for colon cancer occurrence (131). CYP1A2 is one of the class I CYPs, which are distinguished by a well-conserved sequence and lack of functional polymorph. CYP1A2 activity has interindividual (genetic) difference, and this polymorphism is triggered by external factors such as smoking (129). Although downregulated by total extract, artemisinin upregulates the mRNA expression of CYP1A2, CYP2C33, CYP2D25 and CYP3A29 in porcine hepatocyte culture (132), suggesting a shared regulatory mechanism of CYP transcription and an inverse agonist effect of $C$. intybus.

\section{Toxicological studies}

A toxicological study in a 28-day sub-chronic toxicity study of $C$. intybus root extract in male and female Sprague-Dawley rats revealed no adverse effects at $1,000 \mathrm{mg} / \mathrm{kg} /$ day dose (133). The $C$. intybus seed chloroform extract inhibited $50 \%$ cell growth of human colorectal adenocarcinoma cells (HCT-15) at $1,411.37 \mu \mathrm{g} / \mathrm{ml}$ concentration (134). The inhibition of mouse embryo-derived teratocarcinoma cells (P-19) by a methanolic extract of $C$. intybus was least bio-toxic as well as concentration and duration dependent (135). The cytotoxic activity of chlorogenic acid (CGA) at a millimolar concentration was higher in human oral squamous cell carcinoma cells (HSC-2) and a salivary gland tumor cell line (HSG) than in human gingival fibroblast cells (HGF) (136).

\section{Clinical trials}

The number of completed cancer or tumor-related clinical trials of $C$. intybus whole plant or crude or purified extract is inadequate. A phase 1, placebo-controlled, double-blind, dose-escalating trial was performed in patients with osteoarthritis and showed the potential of $C$. intybus root extract in the management of osteoarthritis (137). A second clinical trial reported that daily consumption of chicory coffee reduced the risk of cardiovascular disorder by lowering whole blood and plasma viscosity as well as serum MIF level but had a variable effect on platelet aggregation (138). A multi-herbal liver tonic formula called Liv-52 that contains $C$. intybus as one of the ingredients was tested in a randomized, double-blind, placebo-controlled clinical trial in cirrhotic patients. Liv-52 showed a hepatoprotective effect in cirrhotic patients due to the diuretic, anti-inflammatory, anti-oxidative, and immunomodulating properties of the component herbs (139). A spermidine-rich diet has been linked to increased survival in an animal model (140). Spermidine also reduced the overall (141) and cancer-related (142) mortality in a human clinical trial. In a difluoromethylornithine (DFMO) + sulindac colorectal adenoma prevention trial involving dietary putrescine, spermine and spermidine administration exogenous putrescine effectively increased cellular polyamine concentration and decreased the risk and reoccurrence of metachronous adenomas and advanced adenomas (143). Clinical evidence has shown that artesin derivatives (artemether and artesunate) substantially reduce tumor size, and metastasis and increase the survival of patients with laryngeal carcinoma, uveal melanomas, and pituitary macroadenomas. These derivatives are in phase I-II-III clinical trials for lupus nephritis and breast, colorectal (NCT03093129) and non-small cell lung cancer (NCT02786589) (36,111). Currently, a phase IV clinical trial in China (NCT02556814) is investigating caffeic acid combined with high-dose dexamethasone in the management of immune thrombocytopenia (ITP). Anthocyanin-rich extracts of different plant species have shown promising result in phase I clinical trials, but no convincing evidence has been shown with purified compounds (144). Several clinical trials are currently underway to investigate quercetin. One clinical trial is investigating its chemoprevention activity in squamous cell carcinoma patients (NCT03476330). Two clinical trials are examining quercetin in prostate cancer (NCT01538316), and another is studying the effect of quercetin on green tea polyphenol uptake in prostate tissue from prostate cancer patients undergoing surgery (NCT01912820). One clinical trial in Germany was previously proposed to 
Table II. Chemical groups of Cichorium intybus L.-derived phytochemicals with cell-specific activity.

\begin{tabular}{llll}
\hline Chemical groups/structural motifs & \multicolumn{1}{c}{ Cell lines } & Activity \\
\hline Polyacetylene & MK-1 & Cytotoxic \\
3,4-Dihydroxyphenethyl & B16F10 & Antiproliferative & (46) \\
& HSC-2, HSG & Cytotoxic & (138) \\
6-Methoxyflavone/6-hydroxyflavone & HeLa & Inhibitory \\
Delphinidin & Jurkat, MH7A & Anti-inflammatory \\
Phytosterol/sterol & U937 & Apoptosis \\
& CaCo-2, HepG2 & Necrosis \\
Usnic acid & LNCaP & Apoptosis \\
\hline
\end{tabular}

study the synergic effect of dietary apigenin in combination with epigallocathechin gallate in colorectal cancer patients (NCT00609310), but this study has been suspended. A phase III clinical trial is currently investigating the effect of statins with phytosterol as a dietary intervention in breast cancer patients (NCT03971019). $\beta$-sitosterol was successfully proven to be effective in treating BPH in a phase II clinical trial (145). Inulin is used during acute radiation enteritis to prevent indigestion (146).

\section{Conclusion and perspectives}

C. intybus has been the subject of multiple studies examining its various bioactivities. Here we reviewed numerous reports in regards to the association of $C$. intybus whole, partial, fractionated and purified extracts, with chemotherapeutic properties. Some of the purified compounds from C. intybus demonstrated efficacy in in vitro and in vivo experiments as well as in clinical trials. A few of their functions are associated with the chemicals' structural features such as chemical groups and positioning. Structural activity relationship and molecular mechanisms of toxicity studies have also revealed the importance of certain chemical groups for functionality. The specificities of some phytochemicals towards some specific cell lines (Table II) also indicate structure-specific inhibition activities. Some clinical trials and cytotoxicity studies have examined the whole extract and purified compounds. However, little information is available regarding the molecular mechanism and even fewer clinical trials have investigated these properties, which is not adequate to construct a complete pathway. Further investigation of the following subject areas is crucial for optimizing the therapeutic potential of C.intybus. i) Identification of more phytochemicals and chemical groups or features of existing phytochemicals that interact with the key control points of tumor development. ii) From the above information, it is important to develop a complete model explaining the interaction cascade between phytochemicals and tumor cells and the associated molecular pathways for developing precision medicines. iii) It is vital to investigate the selective cytotoxicity of phytochemicals towards tumor cells and avoiding healthy cells. It is important to confirm the reproducibility of these properties in in vitro, in situ, in vivo and human trials.

All chemotherapeutic products currently available show various levels of indiscriminate cytotoxicity towards normal cells, hindering successful recovery. Moreover, the interpersonal and interorgan difference in metabolic profile makes generic treatment even less effective. A targeted chemotherapeutic product that does not interfere with healthy cells is thus required. Natural compounds usually target cancer cells or their metabolic pathways at the molecular level; therefore, understanding the interaction of phytochemicals with normal and cancer cells is required for designing tumor-specific personalized therapeutics. However, our review suggests that a complete molecular mechanism and clinical study information is lacking for natural bioactive compounds. In regards to the rich historical background of ethnomedicinal use and the scientific findings reported to date, $C$. intybus phytometabolites assuredly show excellent promise as a source of anticancer compounds. Future research should be focused on understanding the correlation between structure and cell specificity, phytochemical isolation and designing derivatives to formulate targeted and efficient therapeutics and prophylactics as well as establishing clinical trials to approve their mainstream use.

\section{Acknowledgements}

We thank Xiaoguo Qian (Fengning Ping'an High-tech Industrial Co., Ltd., Hebei Province, China) for the helpful discussions.

\section{Funding}

This work was supported by the National Key Research and Development Plan 'Modern Food Processing and Food Storage and Transportation Technology and Equipment' (no. 2017YFD0400204).

\section{Availability of data and materials}

Datasets used in this review are summarized and presented with the publication as tables. Any other relevant information will be made available by the corresponding author upon reasonable request.

\section{Authors' contributions}

KMSUI and YX wrote the first draft, developed the figures and tables. YL contributed to the writing and argument 
development. FW and FX jointly made critical revisions and approved the final version. All the authors reviewed and approved the final manuscript.

\section{Ethics approval and consent to participate}

Not applicable.

\section{Patient consent for publication}

Not applicable.

\section{Competing interests}

Authors disclose no potential conflicts of interests

\section{References}

1. Al-Snafi AE: Medical importance of Cichorium intybus-A review. IOSR J Of Pharm 6: 41-56, 2016.

2. Bais HP and Ravishankar GA: Cichorium intybus L- cultivation, processing, utility, value addition and biotechnology, with an emphasis on current status and future prospects. J Sci Food Agric 81: 467-484, 2001.

3. Street RA, Sidana J and Prinsloo G: Cichorium intybus: Traditional uses, phytochemistry, pharmacology, and toxicology. Evid Based Complement Alternat Med 2013: 579319, 2013.

4. Roberfroid MB: Inulin-type fructans: Functional food ingredients. J Nutr 137 (Suppl 11): S2493-S2502, 2007.

5. Carazzone C,Mascherpa D, Gazzani G and Papetti A: Identification of phenolic constituents in red chicory salads (Cichorium intybus) by high-performance liquid chromatography with diode array detection and electrospray ionisation tandem mass spectrometry. Food Chem 138: 1062-1071, 2013.

6. Malik B, Pirzadah TB, Tahir I and Rehman RU: Chemo-profiling, antioxidant potential and ionomic analysis of Cichorium intybus L. Pharmacogn J 9: 917-928, 2017

7. Reuter S, Gupta SC, Chaturvedi MM and Aggarwal BB: Oxidative stress, inflammation, and cancer: How are they linked? Free Radic Biol Med 49: 1603-1616, 2010.

8. Liou GY and Storz P: Reactive oxygen species in cancer. Free Radic Res 44: 479-496, 2010.

9. Moloney JN and Cotter TG: ROS signalling in the biology of cancer. Semin Cell Dev Biol 80: 50-64, 2018.

10. Chen Y, Zhang H, Zhou HJ, Ji W and Min W: Mitochondrial redox signaling and tumor progression. Cancers (Basel) 8: 40, 2016.

11. Saikolappan S, Kumar B, Shishodia G, Koul S and Koul HK: Reactive oxygen species and cancer: A complex interaction. Cancer Lett 452: 132-143, 2019.

12. Conforti F, Ioele G, Statti GA, Marrelli M, Ragno G and Menichini F: Antiproliferative activity against human tumor cell lines and toxicity test on Mediterranean dietary plants. Food Chem Toxicol 46: 3325-3332, 2008.

13. Hafez ESE, Badr EA, Mabrouk YM, Seehy MA and Aggag SA: Expression of tumor-markers and cytokines in response to Cichorium endivia $\mathrm{L}$. in cancerous mice. Int J Life Sci Biotech Pharma Res 3: 1-7, 2014.

14. Alshehri A and Elsayed HE: Molecular and biochemical evaluation of anti-proliferative effect of (Cichorium endivia L.) phenolic extracts on breast cancer cell line: MCF7. J Biotechnol Pharma Res 3: 74-82, 2012.

15. Hafez EE, BadrE, Mabrouk Y,El-Seehy M and Aggag S: Molecular genetic evaluation of Cichorium endivia $\mathrm{L}$. as an anticancer agent against colorectal cancer. Int J Phytomed 8: 551-557, 2016.

16. Hazra B, Sarkar R, Bhattacharyya S and Roy P: Tumour inhibitory activity of chicory root extract against Ehrlich ascites carcinoma in mice. Fitoterapia 73: 730-733, 2002.

17. Nawab A, Yunus M, Mahdi AA and Gupta S: Evaluation of anticancer properties of medicinal plants from the Indiansub-continent. Mol Cell Pharmacol 3: 21-29, 2011.

18. Mehrandish R, Awsat Mellati A, Rahimipour A and Dehghan Nayeri N: Anti-cancer activity of methanol extracts of Cichorium intybus on human breast cancer SKBR3 cell line. Razavi Int J Med 5: e38369, 2017.
19. Saleem M, Abbas K, Naseer F, Mobasher A, Syed NH, Fatima J, Hussain K and Samia A: Anticancer activity of n-hexane extract of Cichorium intybus on lymphoblastic leukemia cells (Jurkat cells). Asian J Plant Sci 8: 315-319, 2014.

20. Esmaeilbeig M, Kouhpayeh SA and Amirghofran Z: An investigation of the growth inhibitory capacity of several medicinal plants from Iran on tumor cell lines. Iran J Cancer Prev 8: e4032, 2015.

21. Leclercq E: Determination of lactucin in roots of chicory (Cichorium intybus L.) by high-performance liquid chromatography. J Chromatogr A 283: 441-444, 1984.

22. Bischoff TA, Kelley CJ,Karchesy Y,Laurantos M,Nguyen-Dinh P and Arefi AG: Antimalarial activity of lactucin and lactucopicrin: Sesquiterpene lactones isolated from Cichorium intybus $\mathrm{L}$. J Ethnopharmacol 95: 455-457, 2004.

23. Kisiel W and Zielińska K: Guaianolides from Cichorium intybus and structure revision of Cichorium sesquiterpene lactones. Phytochemistry 57: 523-527, 2001.

24. Malarz J, Stojakowska A, Szneler E and Kisiel W: A new neolignan glucoside from hairy roots of Cichorium intybus. Phytochem Lett 6: 59-61, 2013.

25. Pyrek JS: Sesquiterpene lactones of Cichorium intybus and Leontodon autumnalis. Phytochemistry 24: 186-188, 1985.

26. Satmbekova D, Srivedavyasasri R, Orazbekov Y, Omarova R, Datkhayev U and Ross SA: Chemical and biological studies on Cichorium intybus L. Nat Prod Res 32: 1343-1347, 2018.

27. Van Beek TA, Maas P, King BM, Leclercq E, Voragen AGJ and De Groot A: Bitter sesquiterpene lactones from chicory roots. J Agric Food Chem 38: 1035-1038, 1990.

28. Nwafor IC, Shale K and Achilonu MC: Chemical composition and nutritive benefits of chicory (Cichorium intybus) as an ideal complementary and/or alternative livestock feed supplement. ScientificWorldJournal 2017: 7343928, 2017.

29. Aisa HA and Xue-Lei X: Cichorium glandulosum Bioss. Et Huet (Juju, Chicory). In: Dietary Chinese Herbs. Springer, Vienna Pharmacology and Clinical Evidence pp711-720, 2015.

30. Malarz J, Stojakowska A and Kisiel W: Long-term cultured hairy roots of chicory-a rich source of hydroxycinnamates and 8-deoxylactucin glucoside. Appl Biochem Biotechnol 171: 1589-1601, 2013.

31. Malarz J, Stojakowska A and Kisiel W: Sesquiterpene lactones in a hairy root culture of Cichorium intybus. Z Naturforsch C 57: 994-997, 2002.

32. Monde K, Oya T, Takasugi M and Shirata A: A guaianolide phytoalexin, cichoralexin, from Cichorium intybus. Phytochemistry 29: 3449-3451, 1990.

33. Seto M, Miyase T, Umehara K, Ueno A, Hirano Y and Otani N: Sesquiterpene lactones from Cichorium endivia L. and C. intybus L. and cytotoxic activity. Chem Pharm Bull (Tokyo) 36: 2423-2429, 1988.

34. Zhang S, Zhao M, Bai L, Hasegawa T, Wang J, Wang L, Xue H, Deng Q, Xing F, Bai Y, et al: Bioactive guaianolides from siyekucai (Ixeris chinensis). J Nat Prod 69: 1425-1428, 2006.

35. Ren Y, Zhou Y, Chen X and Ye Y: Discovery, structural determination and anticancer activities of Lactucin like guaianolides. Lett Drug Des Discov 2: 444-450, 2005.

36. Ghantous A, Gali-Muhtasib H, Vuorela H, Saliba NA and Darwiche N: What made sesquiterpene lactones reach cancer clinical trials? Drug Discov Today 15: 668-678, 2010.

37. Rüngeler P, Castro V, Mora G, Gören N, Vichnewski W, Pahl HL, Merfort I and Schmidt TJ: Inhibition of transcription factor NF-kappaB by sesquiterpene lactones: A proposed molecular mechanism of action. Bioorg Med Chem 7: 2343-2352, 1999.

38. García-Piñeres AJ, Castro V, Mora G, Schmidt TJ, Strunck E, Pahl HL and Merfort I: Cysteine 38 in p65/NF-kappaB plays a crucial role in DNA binding inhibition by sesquiterpene lactones. J Biol Chem 276: 39713-39720, 2001.

39. Krebsky EO, Geuns JMC and De Proft M: Polyamines and sterols in Cichorium heads. Phytochemistry 50: 549-553, 1999.

40. Papetti A, Mascherpa D, Carazzone C, Stauder M, Spratt DA, Wilson M, Pratten J, Ciric L, Lingström P, Zaura E, et al: Identification of organic acids in Cichorium intybus inhibiting virulence-related properties of oral pathogenic bacteria. Food Chem 138: 1706-1712, 2013.

41. Amendola R, Cervelli M, Fratini E, Polticelli F, Sallustio DE and Mariottini P: Spermine metabolism and anticancer therapy. Curr Cancer Drug Targets 9: 118-130, 2009.

42. Cheng B, Bux R and Cheng D: Spermidine/spermine N1-acetyltransferase antibodies as anti-cancer drug compounds. US Patent 2016/0017054 A1. Filed January 30, 2014; issued January 21, 2016. 
43. Kremmer T, Pälyi I, Daubner D, Boldizsár M, Vincze B, Paulik E, Sugár J, Pokorny E and Túry E: Comparative studies on the polyamine metabolism and DFMO treatment of MCF-7 and MDA-MB-231 breast cancer cell lines and xenografts. Anticancer Res 11: 1807-1813, 1991.

44. Lima G and Shiu RP: Role of polyamines in estradiol-induced growth of human breast cancer cells. Cancer Res 45: 2466-2470, 1985.

45. Pályi I, Kremmer T, Kálnay A, Turi G, Mihalik R, Bencsik K and Boldizsár M: Effects of methylacetylenic putrescine, an ornithine decarboxylase inhibitor and potential novel anticancer agent, on human and mouse cancer cell lines. Anticancer Drugs 10: 103-111, 1999.

46. Kinjo J, Nakano D, Fujioka T and Okabe H: Screening of promising chemotherapeutic candidates from plants extracts. J Nat Med 70: 335-360, 2016

47. Lessard M, Zhao C, Singh SM and Poulin R: Hormonal and feedback regulation of putrescine and spermidine transport in human breast cancer cells. J Biol Chem 270: 1685-1694, 1995.

48. Pegg AE and McCann PP: Polyamine metabolism and function. Am J Physiol 243: C212-C221, 1982.

49. Thomas T and Thomas TJ: Polyamines in cell growth and cell death: Molecular mechanisms and therapeutic applications. Cell Mol Life Sci 58: 244-258, 2001.

50. Bridle P, Thomas Loeffler RS, Timberlake CF and Self R: Cyanidin 3 -malonylglucoside in Cichorium intybus. Phytochemistry 23 2968-2969, 1984.

51. Tousch D, Lajoix AD, Hosy E, Azay-Milhau J, Ferrare K, Jahannault C, Cros G and Petit P: Chicoric acid, a new compound able to enhance insulin release and glucose uptake. Biochem Biophys Res Commun 377: 131-135, 2008.

52. Nørbaek R, Nielsen K and Kondo T: Anthocyanins from flowers of Cichorium intybus. Phytochemistry 60: 357-359, 2002.

53. Kurata R, Adachi M, Yamakawa O and Yoshimoto M: Growth suppression of human cancer cells by polyphenolics from sweetpotato (Ipomoea batatas L.) leaves. J Agric Food Chem 55 185-190, 2007.

54. Chen YJ, Shiao MS, Hsu ML, Tsai TH and Wang SY: Effect of caffeic acid phenethyl ester, an antioxidant from propolis, on inducing apoptosis in human leukemic HL-60 cells. J Agric Food Chem 49: 5615-5619, 2001.

55. Kampa M, Alexaki VI, Notas G, Nifli AP, Nistikaki A, Hatzoglou A, Bakogeorgou E, Kouimtzoglou E, Blekas G, Boskou D, et al: Antiproliferative and apoptotic effects of selective phenolic acids on T47D human breast cancer cells: Potential mechanisms of action. Breast Cancer Res 6: R63-R74, 2004

56. Dilshara MG, Jayasooriya RG, Park SR, Choi YH, Choi IW and Kim GY: Caffeic acid phenethyl ester enhances TRAIL-mediated apoptosis via CHOP-induced death receptor 5 upregulation in hepatocarcinoma Hep3B cells. Mol Cell Biochem 418: 13-20, 2016.

57. Búfalo MC, Ferreira I, Costa G, Francisco V, Liberal J, Cruz MT, Lopes MC, Batista MT and Sforcin JM: Propolis and its constituent caffeic acid suppress LPS-stimulated pro-inflammatory response by blocking NF- $\kappa \mathrm{B}$ and MAPK activation in macrophages. J Ethnopharmacol 149: 84-92, 2013.

58. Huang MT, Smart RC, Wong CQ and Conney AH: Inhibitory effect of curcumin, chlorogenic acid, caffeic acid, and ferulic acidon tumor promotion in mouse skin by 12-O-tetradecanoylphorbol-13-acetate. Cancer Res 48: 5941-5946, 1988.

59. Kasai H, Fukada S, Yamaizumi Z, Sugie S and Mori H: Action of chlorogenic acid in vegetables and fruits as an inhibitor of 8-hydroxydeoxyguanosine formation in vitro and in a rat carcinogenesis model. Food Chem Toxicol 38: 467-471, 2000.

60. Feng R, Lu Y, Bowman LL, Qian Y, Castranova V and Ding M: Inhibition of activator protein-1, NF-kappaB, and MAPKs and induction of phase 2 detoxifying enzyme activity by chlorogenic acid. J Biol Chem 280: 27888-27895, 2005.

61. Wang GF, Shi LP, Ren YD, Liu QF, Liu HF, Zhang RJ, Li Z, Zhu FH, He PL, Tang W, et al: Anti-hepatitis B virus activity of chlorogenic acid, quinic acid and caffeic acid in vivo and in vitro. Antiviral Res 83: 186-190, 2009.

62. Hsu CL, Huang SL and Yen GC: Inhibitory effect of phenolic acids on the proliferation of 3T3-L1 preadipocytes in relation to their antioxidant activity. J Agric Food Chem 54: 4191-4197, 2006

63. Maki C, Funakoshi-Tago M, Aoyagi R, Ueda F, Kimura M Kobata K, Tago K and Tamura H: Coffee extract inhibits adipogenesis in 3T3-L1 preadipocyes by interrupting insulin signaling through the downregulation of IRS1. PLoS One 12: e0173264, 2017.
64. Meng S, Cao J, Feng Q, Peng J and Hu Y: Roles of chlorogenic acid on regulating glucose and lipids metabolism: A review. Evid Based Complement Alternat Med 2013: 801457, 2013.

65. Olthof MR, Hollman PCH and Katan MB: Chlorogenic acid and caffeic acid are absorbed in humans. J Nutr 131: 66-71, 2001

66. In JK, Kim JK, Oh JS and Seo DW: 5-Caffeoylquinic acid inhibits invasion of non-small cell lung cancer cells through the inactivation of p70S6K and Akt activity: Involvement of p53 in differential regulation of signaling pathways. Int J Oncol 48: 1907-1912, 2016.

67. Apostolou A, Stagos D, Galitsiou E, Spyrou A, Haroutounian S Portesis N, Trizoglou I, Wallace Hayes A, Tsatsakis AM and Kouretas D: Assessment of polyphenolic content, antioxidant activity, protection against ROS-induced DNA damage and anticancer activity of Vitis vinifera stem extracts. Food Chem Toxicol 61: 60-68, 2013.

68. Kirmizibekmez H, Calis I, Perozzo R, Brun R, Dönmez AA, Linden A, Rüedi P and Tasdemir D: Inhibiting activities of the secondary metabolites of Phlomis brunneogaleata against parasitic protozoa and plasmodial enoyl-ACP Reductase, a crucial enzyme in fatty acid biosynthesis. Planta Med 70: 711-717, 2004.

69. You Q, Chen F, Ni H, Wang X, Jiang Y and McCoy JA: HPLC-MS analyses and bioactivities of novel chemicals in Devil's club (Oplopanax horridus (Sm.) Miq.). Food Chem 135: 199-207, 2012.

70. Park CM, Jin KS, Lee YW and Song YS: Luteolin and chicoric acid synergistically inhibited inflammatory responses via inactivation of PI3K-Akt pathway and impairment of NF- $\mathrm{B}$ translocation in LPS stimulated RAW 264.7 cells. Eur J Pharmacol 660: 454-459, 2011.

71. Xiao H, Wang J, Yuan L, Xiao C, Wang Y and Liu X: Chicoric acid induces apoptosis in 3T3-L1 preadipocytes through ROS-mediated PI3K/Akt and MAPK signaling pathways. J Agric Food Chem 61: 1509-1520, 2013.

72. Huntimer ED, Halaweish FT and Chase CCL: Proliferative activity of Echinacea angustifolia root extracts on cancer cells: Interference with doxorubicin cytotoxicity. Chem Biodivers 3 : 695-703, 2006.

73. Zhou J, Fang L, Liao J, Li L, Yao W, Xiong Z and Zhou X: Investigation of the anti-cancer effect of quercetin on HepG2 cells in vivo. PLoS One 12: e0172838, 2017.

74. Saleh MR, Metwally AM and Amer MM: Isolation of a flavonoidal substance from Cichorium pumilum jacq. Pharmazie 30: 404, 1975.

75. Chen Z, Liu YM, Yang S, Song BA, Xu GF, Bhadury PS, Jin LH, $\mathrm{Hu}$ DY, Liu F, Xue W and Zhou X: Studies on the chemical constituents and anticancer activity of Saxifraga stolonifera (L) Meeb. Bioorg Med Chem 16: 1337-1344, 2008.

76. Maiyo FC, Moodley R and Singh M: Cytotoxicity, antioxidant and apoptosis studies of quercetin-3-O glucoside and 4-( $\beta-D-$ glucopyranosyl-1 $\rightarrow 4-\alpha$-L-rhamnopyranosyloxy)-benzyl isothiocyanate from Moringa oleifera. Anticancer Agents Med Chem 16: 648-656, 2016.

77. Panat NA, Amrute KB, Battu S, Haram S, Sharma G and Ghaskadbi S: Antioxidant profiling of C3 quercetin glycosides: Quercitrin, quercetin 3- $\beta$-D-glucoside and quercetin 3 -O-(6"-O-malonyl)- $\beta$-D-glucoside in cell free environment. Free Rad Antiox 5: 90-100, 2015.

78. Sassi N, Mattarei A, Espina V, Liotta L, Zoratti M, Paradisi C and Biasutto L: Potential anti-cancer activity of 7-O-pentyl quercetin: Efficient, membrane-targeted kinase inhibition and pro-oxidant effect. Pharmacol Res 124: 9-19, 2017.

79. Sugantha Priya E, Selvakumar Benny K, Bavithra S, Elumalai $P$ Arunkumar R, Raja Singh P, Brindha Mercy A and Arunakaran J: Anti-cancer activity of quercetin in neuroblastoma: An in vitro approach. Neurol Sci 35: 163-170, 2014.

80. Danino O, Gottlieb HE, Grossman S and Bergman M: Antioxidant activity of 1,3-dicaffeoylquinic acid isolated from Inula viscosa. Food Res Int 42: 1273-1280, 2009.

81. Chen PN, Chu SC, Chiou HL, Chiang CL, Yang SF and Hsieh YS: Cyanidin 3-glucoside and peonidin 3-glucoside inhibit tumor cell growth and induce apoptosis in vitro and suppress tumor growth in vivo. Nutr Cancer 53: 232-243, 2005.

82. Cho E, Chung EY, Jang HY, Hong OY, Chae HS, Jeong YJ, Kim SY, Kim BS, Yoo DJ, Kim JS and Park KH: Anti-cancer effect of cyanidin-3-glucoside from mulberry via caspase-3 cleavage and DNA fragmentation in vitro and in vivo. Anticancer Agents Med Chem 17: 1519-1525, 2017.

83. Lee JS, Kim YR, Song IG, Ha SJ, Kim YE, Baek NI and Hong EK: Cyanidin-3-glucoside isolated from mulberry fruit protects pancreatic $\beta$-cells against oxidative stress-induced apoptosis. Int J Mol Med 35: 405-412, 2015. 
84. Meiers S, Kemény M, Weyand U, Gastpar R, von Angerer E and Marko D: The anthocyanidins cyanidin and delphinidin are potent inhibitors of the epidermal growth-factor receptor. J Agric Food Chem 49: 958-962, 2001.

85. Srivastava JK and Gupta S: Extraction, characterization, stability and biological activity of flavonoids isolated from Chamomile flowers. Mol Cell Pharmacol 1: 138, 2009.

86. Smiljkovic M, Stanisavljevic D, Stojkovic D, Petrovic I, Marjanovic Vicentic J, Popovic J, Golic Grdadolnik S, Markovic D, Sankovic-Babice S, Glamoclija J, et al: Apigenin-7-O-glucoside versus apigenin: Insight into the modes of anticandidal and cytotoxic actions. EXCLI J 16: 795-807, 2017.

87. Xu W, Liu J, Li C, Wu HZ and Liu YW: Kaempferol-7-Obeta-D-glucoside $(\mathrm{KG})$ isolated from Smilax china L. rhizome induces $\mathrm{G} 2 / \mathrm{M}$ phase arrest and apoptosis on HeLa cells in a p53-independent manner. Cancer Lett 264: 229-240, 2008.

88. Nasri I, Chawech R, Girardi C, Mas E, Ferrand A, Vergnolle N, Fabre N, Mezghani-Jarraya R and Racaud-Sultan C: Anti-inflammatory and anticancer effects of flavonol glycosides from Diplotaxis harra through GSK $3 \beta$ regulation in intestinal cells. Pharm Biol 55: 124-131, 2017.

89. Park JY, Kim SI, Lee HJ, Kim SS, Kwon YS and Chun W: Isorhamnetin-3-O-glucuronide suppresses JNK and p38 activation and increases heme-oxygenase-1 in lipopolysaccharidechallenged RAW264.7 cells. Drug Dev Res 77: 143-151, 2016

90. Yang X, Luo E, Liu X, Han B, Yu X and Peng X: Delphinidin3 -glucoside suppresses breast carcinogenesis by inactivating the Akt/HOTAIR signaling pathway. BMC Cancer 16: 423, 2016.

91. He X and Liu RH: Cranberry phytochemicals: Isolation, structure elucidation, and their antiproliferative and antioxidant activities. J Agric Food Chem 54: 7069-7074, 2006.

92. Ghosh T, Maity T and Singh J: Evaluation of antitumor activity of stigmasterol, a constituent isolated from Bacopa monnieri Linn aerial parts against ehrlich ascites carcinoma in mice. Orient Pharm Exp Med 11: 41-49, 2011.

93. Kangsamaksin T, Chaithongyot S, Wootthichairangsan C, Hanchaina R, Tangshewinsirikul C and Svasti J: Lupeol and stigmasterol suppress tumor angiogenesis and inhibit cholangiocarcinoma growth in mice via downregulation of tumor necrosis factor- $\alpha$. PLoS One 12: e0189628, 2017.

94. Syed Abdul Rahman SN, Abdul Wahab N and Abd Malek SN: In vitro morphological assessment of apoptosis induced by antiproliferative constituents from the rhizomes of Curcuma zedoaria. Evid Based Complement Alternat Med 2013: 257108, 2013.

95. Dutra LM, Bomfim LM, Rocha SL, Nepel A, Soares MB, Barison A, Costa EV and Bezerra DP: ent-Kaurane diterpenes from the stem bark of Annona vepretorum (Annonaceae) and cytotoxic evaluation. Bioorg Med Chem Lett 24: 3315-3320, 2014

96. Ali H, Dixit S, Ali D, Alqahtani SM, Alkahtani S and Alarifi S: Isolation and evaluation of anticancer efficacy of stigmasterol in a mouse model of DMBA-induced skin carcinoma. Drug Des Devel Ther 9: 2793-2800, 2015.

97. Süntar I, Küpeli Akkol E, Keles H, Yesilada E, Sarker SD and Baykal T: Comparative evaluation of traditional prescriptions from Cichorium intybus L. for wound healing: Stepwise isolation of an active component by in vivo bioassay and its mode of activity. J Ethnopharmacol 143: 299-309, 2012.

98. Woyengo TA, Ramprasath VR and Jones PJ: Anticancer effects of phytosterols. Eur J Clin Nutr 63: 813-820, 2009.

99. Cheng D, Guo Z and Zhang S: Effect of $\beta$-sitosterol on the expression of HPV E6 and p53 in cervical carcinoma cells. Contemp Oncol (Pozn) 19: 36-42, 2015.

100. Awad AB, Chinnam M, Fink CS and Bradford PG: $\beta$-Sitosterol activates Fas signaling in human breast cancer cells. Phytomedicine 14: 747-754, 2007.

101. Chai JW, Kuppusamy UR and Kanthimathi MS: Beta-sitosterol induces apoptosis in MCF7 cells. Malays J Biochem Mol Biol 16: 28-30, 2008.

102. Wilt TJ, Ishani A, MacDonald R, Stark G, Mulrow CD and Lau J: Beta-sitosterols for benign prostatic hyperplasia. Cochrane Database Syst Rev: CD001043, 2000.

103. Nibret E, Youns M, Krauth-Siegel RL and Wink M: Biological activities of xanthatin from Xanthium strumarium leaves. Phytother Res 25: 1883-1890, 2011.

104. Ryan E, Chopra J, McCarthy F, Maguire AR and O'Brien NM: Qualitative and quantitative comparison of the cytotoxic and apoptotic potential of phytosterol oxidation products with their corresponding cholesterol oxidation products. Br J Nutr 94 443-451, 2005 .
105. O'Callaghan Y, McCarthy FO and O'Brien NM: Recent advances in phytosterol oxidation products. Biochem Biophys Res Commun 446: 786-791, 2014

106. Oliveira H, Wu N, Zhang Q, Wang J, Oliveira J, de Freitas V, Mateus N, He J and Fernandes I: Bioavailability studies and anticancer properties of malvidin based anthocyanins, pyranoanthocyanins and non-oxonium derivatives. Food Funct 7: 2462-2468, 2016

107. Amini AM, Spencer JPE and Yaqoob P: Effects of pelargonidin-3-O-glucoside and its metabolites on lipopolysaccharide-stimulated cytokine production by THP-1 monocytes and macrophages. Cytokine 103: 29-33, 2018.

108. Duarte LJ, Chaves VC, Nascimento MVPDS, Calvete E, Li M, Ciraolo E, Ghigo A, Hirsch E, Simões CMO, Reginatto FH and Dalmarco EM: Molecular mechanism of action of Pelargonidin-3-O-glucoside, the main anthocyanin responsible for the anti-inflammatory effect of strawberry fruits. Food Chem 247: 56-65, 2018.

109. Seong AR, Yoo JY, Choi K, Lee MH, Lee YH, Lee J, Jun W, Kim S and Yoon HG: Delphinidin, a specific inhibitor of histone acetyltransferase, suppresses inflammatory signaling via prevention of NF- $\kappa$ B acetylation in fibroblast-like synoviocyte MH7A cells. Biochem Biophys Res Commun 410: 581-586, 2011.

110. Wang LS and Stoner GD: Anthocyanins and their role in cancer prevention. Cancer Lett 269: 281-290, 2008.

111. Das AK: Anticancer effect of Antimalarial artemisinin compounds. Ann Med Health Sci Res 5: 93-102, 2015.

112. Slezakova S and Ruda-Kucerova J: Anticancer activity of artemisinin and its derivatives. Anticancer Res 37: 5995-6003, 2017.

113. Wong YK, Xu C, Kalesh KA, He Y, Lin Q, Wong WSF, Shen HM and Wang J: Artemisinin as an anticancer drug: Recent advances in target profiling and mechanisms of action. Med Res Rev 37: 1492-1517, 2017

114. Crespo-Ortiz MP and Wei MQ: Antitumor activity of artemisinin and its derivatives: From a well-known antimalarial agent to a potential anticancer drug. J Biomed Biotechnol 2012: $247597,2012$.

115. Gravett AM, Liu WM, Krishna S, Chan WC, Haynes RK, Wilson NL and Dalgleish AG: In vitro study of the anti-cancer effects of artemisone alone or in combination with other chemotherapeutic agents. Cancer Chemother Pharmacol 67: 569-577, 2011.

116. Alotaibi KS, Li H, Rafi R and Siddiqui RA: Papaya black seeds have beneficial anticancer effects on PC-3 prostate cancer cells J Cancer Metastasis Treat 3: 161-168, 2017.

117. Mayer M, O'Neill MA, Murray KE, Santos-Magalhães NS, Carneiro-Leão AM, Thompson AM and Appleyard VC: Usnic acid: A non-genotoxic compound with anti-cancer properties. Anticancer Drugs 16: 805-809, 2005.

118. Eryilmaz IE, Eskiler GG, Yurdacan B, Egeli Ü, Çeçener G and Tunca B: The cytotoxic and apoptotic effects of usnic acid on prostate cancer versus normal cells. Proceedings 1: 1027, 2017.

119. Yang Y, Nguyen TT, Jeong MH, Crişan F, Yu YH, Ha HH, Choi KH, Jeong HG, Jeong TC, Lee KY, et al: Inhibitory activity of (+)-usnic acid against non-small cell lung cancer cell motility. PLoS One 11: e0146575, 2016.

120. Couri S, Gomes F, Nogueira R and Almeida DL: Determination of inulin content of chicory roots (Cichorium intybus L.) cultivated organically in three regions of Rio de Janeiro state. 2018.

121. Pool-Zobel B, van Loo J, Rowland I and Roberfroid MB: Experimental evidences on the potential of prebiotic fructans to reduce the risk of colon cancer. Br J Nutr 87 (Suppl 2): S273-S281, 2002.

122. Taper HS and Roberfroid MB: Possible adjuvant cancer therapy by two prebiotics-Inulin or oligofructose. In Vivo 19: 201-204, 2005.

123. Taper HS and Roberfroid M: Influence of inulin and oligofructose on breast cancer and tumor growth. J Nutr 129 (Suppl 7): S1488-S1491, 1999.

124. Reddy BS, Hamid R and Rao CV: Effect of dietary oligofructose and inulin on colonic preneoplastic aberrant crypt foci inhibition. Carcinogenesis 18: 1371-1374, 1997.

125. Epstein JI, Carmichael M and Partin AW: OA-519 (fatty acid synthase) as an independent predictor of pathologic state in adenocarcinoma of the prostate. Urology 45: 81-86, 1995.

126. Park MH and Hong JT: Roles of NF- $\mathrm{BB}$ in cancer and inflammatory diseases and their therapeutic approaches. Cells 5: E15, 2016.

127. Tak PP and Firestein GS: NF-kappaB: A key role in inflammatory diseases. J Clin Invest 107: 7-11, 2001. 
128. Rasmussen MK, Zamaratskaia G and Ekstrand B: In vivo effect of dried chicory root (Cichorium intybus L.) on xenobiotica metabolising cytochrome P450 enzymes in porcine liver. Toxicol Lett 200: 88-91, 2011.

129. Rodriguez-Antona $C$ and Ingelman-Sundberg M: Cytochrome P450 pharmacogenetics and cancer. Oncogene 25: 1679-1691, 2006.

130. Chang TKH: Activation of pregnane $X$ receptor (PXR) and constitutive androstane receptor (CAR) by herbal medicines. AAPS J 11: 590-601, 2009.

131. Zuccato E, Venturi M, Di Leo G, Colombo L, Bertolo C, Doldi SB and Mussini E: Role of bile acids and metabolic activity of colonic bacteria in increased risk of colon cancer after cholecystectomy. Dig Dis Sci 38: 514-519, 1993.

132. Rasmussen MK, Klausen CL and Ekstrand B: Regulation of cytochrome P450 mRNA expression in primary porcine hepatocytes by selected secondary plant metabolites from chicory (Cichorium intybus L.). Food Chem 146: 255-263, 2014.

133. Schmidt BM, Ilic N, Poulev A and Raskin I: Toxicological evaluation of a chicory root extract. Food Chem Toxicol 45: 1131-1139, 2007.

134. Mali P: Cytotoxicity activities of chloroform extract of Cichorium intybus seed against HCT-15 and Vero cell line. Int J Health Allied Sci 4: 267-270, 2015.

135. Soltanian S, Sheikhbahaei M and Mohamadi N: Cytotoxicity evaluation of methanol extracts of some medicinal plants on P19 embryonal carcinoma cells. J Appl Pharm Sci 7: 142-149, 2017.

136. Jiang Y, Kusama K, Satoh K, Takayama E, Watanabe S and Sakagami H: Induction of cytotoxicity by chlorogenic acid in human oral tumor cell lines. Phytomedicine 7: 483-491, 2000.

137. Schumacher E, Vigh E, Molnár V, Kenyeres P, Fehér G Késmárky G, Tóth K and Garai J: Thrombosis preventive potential of chicory coffee consumption: A clinical study. Phytother Res 25: 744-748, 2011.

138. Olsen NJ, Branch VK, Jonnala G, Seskar M and Cooper M: Phase 1, placebo-controlled, dose escalation trial of chicory root extract in patients with osteoarthritis of the hip or knee. BMC Musculoskelet Disord 11: 156, 2010.
139. Huseini HF, Alavian SM, Heshmat R, Heydari MR and Abolmaali K: The efficacy of Liv-52 on liver cirrhotic patients: A randomized, double-blind, placebo-controlled first approach. Phytomedicine 12: 619-624, 2005.

140. Soda K, Dobashi Y, Kano Y, Tsujinaka S and Konishi F: Polyamine-rich food decreases age-associated pathology and mortality in aged mice. Exp Gerontol 44: 727-732, 2009.

141. Kiechl S, Pechlaner R, Willeit P, Notdurfter M, Paulweber B, Willeit K, Werner P, Ruckenstuhl C, Iglseder B, Weger S, et al: Higher spermidine intake is linked to lower mortality: A prospective population-based study. Am J Clin Nutr 108: 371-380, 2018.

142. Pietrocola F, Castoldi F, Kepp O, Carmona-Gutierrez D, Madeo F and Kroemer G: Spermidine reduces cancer-related mortality in humans. Autophagy 15: 362-365, 2019.

143. Raj KP, Zell JA, Rock CL, McLaren CE, Zoumas-Morse C, Gerner EW and Meyskens FL: Role of dietary polyamines in a phase III clinical trial of difluoromethylornithine (DFMO) and sulindac for prevention of sporadic colorectal adenomas. $\mathrm{Br}$ J Cancer 108: 512-518, 2013.

144. Imam KMSU, Azam FMS, Jahan R and Rahmatullah M: Anticancer properties of anthocyanins: A review. In: Natural Products: Research Reviews. Gupta VK (ed). Vol 4. Daya Publishing House, pp1-20, 2016.

145. Klippel KF, Hiltl DM and Schipp B: A multicentric, placebocontrolled, double-blind clinical trial of beta-sitosterol (phytosterol) for the treatment of benign prostatic hyperplasia. German BPH-Phyto Study group. Br J Urol 80: 427-432, 1997.

146. Garcia-Peris P, Velasco C, Hernandez M, Lozano MA, Paron L, de la Cuerda C, Breton I, Camblor M and Guarner F: Effect of inulin and fructo-oligosaccharide on the prevention of acute radiation enteritis in patients with gynecological cancer and impact on quality-of-life: A randomized, double-blind, placebo-controlled trial. Eur J Clin Nurtr 70: 170-174, 2016.

147. Rosa LS, Silva NJA, Soares NCP, Monteiro MC and Teodoro AJ: Anticancer properties of phenolic acids in colon cancer a review. J Nutr Food Sci 6: 468, 2016. 